\title{
Novel silver(I) complexes of coumarin oxyacetate ligands and their phenanthroline adducts: Biological activity, structural and spectroscopic characterisation
}

\author{
Muhammad Mujahid a , Natasha Trendafilova ${ }^{\mathrm{b}}$, Agnieszka Foltyn Arfa-Kia a , Georgina Rosair ${ }^{\mathrm{c}}$, \\ Kevin Kavanagh ${ }^{\mathrm{d}}$, Michael Devereux ${ }^{\mathrm{e}}$, Maureen Walsh ${ }^{\mathrm{a}}$, Siobhán McClean ${ }^{\mathrm{a}}$, \\ Bernadette S. Creaven ${ }^{\mathrm{a}, *}$, Ivelina Georgieva ${ }^{\mathrm{b}, *}$ \\ a Centre of Applied Science for Health, Institute of Technology Tallaght, Dublin 24, Ireland \\ b Institute of General and Inorganic Chemistry, Bulgarian Academy of Sciences, 11 Acad. G. Bonchev Str., Sofia, Bulgaria \\ ' School of Engineering \&' Physical Sciences, Heriot-Watt University, Edinburgh EH14 4AS, Scotland, UK \\ ${ }^{\mathrm{d}}$ Department of Biology, National University of Ireland, Maynooth, Co. Kildare, Ireland \\ e The Centre for Biomimetic and Therapeutic Research (CBTR), College of Sciences and Health, Dublin Institute of Technology, Camden Row, Dublin 8, Ireland
}

\section{A R T I C L E I N F O}

\section{Article history:}

Received 8 January 2016

Received in revised form 5 July 2016

Accepted 13 July 2016

Available online 16 July 2016

\section{Keywords:}

Coumarin

Phenanthroline

$\mathrm{Ag}(\mathrm{I})$ complexes

DFT modeling

Biological activity

X-ray structure

\begin{abstract}
A B S T R A C T
Novel silver(I) complexes of coumarin oxyacetate ligands and their phenanthroline adducts have been prepared and characterised by microanalytical data and spectroscopic techniques (IR, ${ }^{1} \mathrm{H},{ }^{13} \mathrm{C} N M R$, UV-Vis). The crystal structure of one $\mathrm{Ag}(\mathrm{I})$ complex was determined by X-ray diffraction analysis. The experimental spectroscopic data have been interpreted on the basis of molecular structure modeling and subsequent spectra simulation with density functional theory method. The binding modes of the coumarins and phenanthroline ligands (monodentate, bidentate, bridging) to $\mathrm{Ag}(\mathrm{I})$ have been theoretically modelled and discussed as to the most probable ligand binding in the series of complexes studied. The antimicrobial and antifungal activities have been determined and the complexes were found to have mostly moderate antibacterial activity but some of the phenanthroline adducts were found to have antifungal activity against the clinically important fungus C. albicans, comparable to that of the commercial agents, Amphotericin B and Ketoconazole. Preliminary investigations into the possible mechanism of action of the silver complexes indicated that they did not interact with DNA via nuclease activity or intercalation but the ability to act as a superoxide dismutase mimetic may be related to their antimicrobial activity.
\end{abstract}

() 2016 Elsevier Inc. All rights reserved.

\section{Introduction}

Several multidrug resistant (MDR) strains of bacteria such as fluoroquinolone- and carbapenem-resistant Pseudomonas aeruginosa and vancomycin-resistant Staphylococcus aureus have emerged as a result of the ability of microbes to adapt to continuously changing environments [1-5]. Treatment of resistant bacterial strains has become a major problem with rising mortality rates and extended hospitalisation for patients translating into ever increasing health care costs, with a report in 2015 estimating that cost to the EU to be at 1.5 billion euro annually [6]. Common pathogens such as $S$. aureus are responsible for harmful infections including mastitis, upper respiratory complications, bacteraemia, pneumonia, skin and soft tissue infections. In particular, S. aureus causes a diversity of infections, from skin infections to disseminated systemic infections leading to organ failure and death $[3,7,8]$. These pathogens can easily be

\footnotetext{
* Corresponding authors.

E-mail addresses: bernie.creaven@ittdublin.ie (B.S. Creaven), ivelina@svr.igic.bas.bg (I. Georgieva).
}

transmitted between patients and have become resistant to different classes of antibiotic drugs, e.g., some strains of methicillin resistant $S$. aureus (MRSA) are often resistant to several antibiotics, including penicillins and cephalosporins [9-11]. In Western Europe a review of intensive care unit infections found that $P$. aeruginosa was identified as one of the most common organisms, constituting nearly a third (29\%) of all Gramnegative isolates, and was present in $17 \%$ of all positive cultures [12]. In addition, in 2013, the Centre for Disease Control and Prevention published a report outlining the threat posed by MDR Gram-negative pathogens and highlighted that the world is currently running out of drugs to treat several Gram-negative infections [13].

The number of incidences of serious fungal infections is also increasing dramatically and with it a rise in resistance to antifungal treatment and its associated healthcare costs. Individuals with weakened immune systems are more likely to get fungal infections. These individuals are either victims of Acquired Immune Deficiency Syndrome (AIDS) or cancer patients receiving aggressive chemotherapy, or following organ transplantation and long hospitalisation [14]. Candida albicans is a causal agent of opportunistic oral and genital infections in humans. It can also form biofilms on 
the surface of implantable medical devices. In addition, it is a major pathogen causing systemic fungal infections as well as hospital-acquired infections and has become an important clinical problem [15]. It is responsible for several infections in humans including deep mycoses, bloodstream infections, mouth, skin, vaginal and human immunodeficiency virus (HIV)related infections as well as Candidiasis [16,17]. Oral infections can be treated with drugs such as Fluconazole and Ketoconazole or typically with polyene-based Amphotericin B and systemic fungal infections can be treated with intravenous administration of Amphotericin B or caspofungin. However, azole-resistant strains of Candida albicans have emerged and these have created problems for administering azolebased treatments [18]. In addition, some of these drugs, such as Amphotericin B are nephrotoxic and damage host cells [14]. The increasing incidence of antifungal resistance in Candida spp. reflects the extensive and escalating use of newer broad-spectrum antifungal agents and thus presents a serious threat to patients worldwide $[19,20]$.

Generally, silver(I) complexes are known to possess significant antibacterial activities against Gram-positive and Gram-negative bacteria and have shown excellent activity against $C$. albicans [21-26]. In recent reviews the applications of silver(I) metallodrugs and current silverbased antimicrobial therapeutics which are commercially available are discussed in detail $[27,28]$. More recently the synthesis of silver/amino acid biopolymer hydrogels as mouldable wound dressings have also been reported [29-31]. Thus the role of silver(I), acting as a free ion, or in compounds such as sulfadiazine or as a hydrogel or nanoparticle has been well established. We have been interested in silver(I) complexes of coumarins for a number of years and they have shown activity against a number of antibiotic and antifungal resistant strains. Coumarins are a class of compounds which occur naturally in many plants and have revealed a diverse array of pharmacological properties [32]. Previous studies have shown that silver(I) complexes of coumarin-3carboxylates and coumarin-4-carboxylates have excellent activity against MRSA and P. aeruginosa respectively [21,33,34]. Exposure of $S$. aureus to silver nitrate has been shown to lead to a transient increase in superoxide dismutase (SOD) activity and catalase activity which may indicate that the silver compound induces oxidative stress in the cell [35]. A more recent paper has shown that silver enhances antibiotic activity against Gram-negative bacteria by interfering with cellular processes and sensitizing the cells towards current antibiotics [36]. The authors reported that the presence of silver appeared to induce oxidative stress in treated cells. We have recently reported a series of water-soluble and photo-stable silver(I) dicarboyxlate complexes with excellent antimicrobial activity and anticancer activity. Interestingly these complexes appeared to have a different mechanism of action to other silver(I) compounds in that they did not induce deoxyribonucleic acid (DNA) damage or reactive oxygen species (ROS) generation and in fact seemed to act as antioxidants in the systems studied, significantly reducing superoxide and hydrogen peroxide induced oxidative stress in the yeast $S$. cerevisiae [37].

The results of our previous studies have also shown that the mode of antifungal action for the silver(I) coumarin-based complexes was based on their interference with respiration in the fungal cells, resulting in reduced ergosterol synthesis and cytochrome production [38]. This mode of action is different to conventional azole and polyene drugs (which bind to ergosterol or block ergosterol biosynthesis, respectively) and thus they looked like promising candidates for new antifungal treatment. Subsequent studies on related phenanthroline adducts of these complexes and other related phenanthroline silver(I) adducts showed that their mechanism of action was based on disruption of mitochondrial function also [39].

In all of the coumarin complexes previously studied, their solubility was of concern to us and in many studies the complexes were tested as suspensions. In an attempt to improve the activity of coumarin carboxylate silver(I) complexes by means of higher solubility and better pharmacological properties we succeeded in isolating a series of $\mathrm{Ag}(\mathrm{I})$ complexes with coumarin oxyacetate ligands in the 3-, 4-, as well as the 6- and 7- positions on the aromatic ring. In addition, their 1,10-phenanthroline (phen) adducts were prepared as the solubility and biological activities of the complexes are also known to increase significantly upon adduct formation with phen [40-44]. The novel $\mathrm{Ag}(\mathrm{I})$ complexes were characterised by experimental physico-chemical and spectroscopic (IR, ${ }^{1} \mathrm{H},{ }^{13} \mathrm{C}$ NMR and UV-Vis) studies in solid state and in solution and by $\mathrm{X}$-ray diffraction analysis. In addition, density functional theory (DFT) modeling of the compounds studied was performed to support or predict the metal-ligand binding mode in the coumarin oxyacetate-derived silver(I) complexes and their phen adducts based on the good agreement between the experimental and calculated spectroscopic data.

\section{Experimental}

\subsection{Reagents and instruments}

Chemicals and solvents were purchased from Sigma-Aldrich Co. (Dorset, UK) and used without further purification. Melting points were recorded on a Stuart Scientific SMP-1 apparatus (up to $300{ }^{\circ} \mathrm{C}$ ). Thin layer chromatographic (TLC) study was carried out on Silica gel $60 \mathrm{~F}_{254}$ aluminium-backed plates using a pre-saturated elution tank. The compounds were detected under ultraviolet light and stained using iodine crystals in a closed chamber. Infrared spectra of solids (as a dispersion in $\mathrm{KBr}$ disc) were recorded on a Nicolet Avatar 320 FT-IR spectrophotometer operating at a resolution of $2 \mathrm{~cm}^{-1}$ in the $4000-400 \mathrm{~cm}^{-1}$ region. The Bruker Biospin 300 and $500 \mathrm{MHz}$ FT-NMR spectrometers were used to record ${ }^{\mathbf{1}} \mathbf{H}$ NMR spectra ( -5 to $15 \mathrm{ppm}$ with a resolution of $0.18 \mathrm{~Hz}$ ) and ${ }^{\mathbf{1 3}} \mathbf{C}$ NMR spectra ( -33 to $233 \mathrm{ppm}$ with a resolution of $2.40 \mathrm{~Hz}$ ) as solutions in dimethyl sulfoxide (DMSO- $d_{6}$ ) using tetramethylsilane (TMS) as the internal reference standard. The signal assignments were made using standard techniques including distortionless enhancement by polarization transfer (DEPT), homonuclear correlation spectra (COSY) and $\mathrm{CH}$ Shift. Where necessary, Heteronuclear Single Quantum Correlation (HSQC), Heteronuclear Multiple Bond Correlation (HMBC) and Nuclear Overhauser effect spectroscopy (NOESY) experiments were also run to facilitate peak assignments. Microanalytical data were provided by the Microanalytical Laboratory, Department of Chemistry, University College Dublin, Belfield, Dublin-4, Ireland, using a PerkinElmer CHN analyser. Silver content was determined using atomic absorption spectroscopy on a PerkinElmer 460AAS instrument. All samples were analysed in triplicate. UV-Vis spectra of the complexes and their corresponding ligands were recorded on a PG Instruments T80 UV/Vis spectrophotometer in DMSO solvent (260-800 nm). The molar conductivity of the complexes and their corresponding ligands was measured on an EUTOH INSTRUMENTS Cyberscan-500 digital conductometer, using $4 \mathrm{mM}$ solution of compounds in DMSO at $25^{\circ} \mathrm{C}$. The metal and water contents of the complexes were determined by using thermogravimetric technique. Thermogravimetric analysis (TGA) was carried out in the temperature range from 25 to $800^{\circ} \mathrm{C}$ in a nitrogen atmosphere using TA Instrument's Q50 Thermogravimetric analyser. The experimental conditions were: platinum weighing pan, nitrogen atmosphere with a $60 \mathrm{ml} / \mathrm{min}$ flow rate and a heating rate of $10^{\circ} \mathrm{C} / \mathrm{min}$.

A single crystal was coated in Paratone- $\mathrm{N}$ heavy oil then mounted on a Hampton Research Cryoloop and placed in a cold stream of nitrogen gas $(100 \mathrm{~K})$ on a Bruker Nonius $\times 8$ Apex 2 CCD diffractometer running the Apex2 software (Bruker 2011). Data collection consisted of, on average, 3000 frames from a combination of phi and omega scans. After unit cell determination, intensity data were integrated using SAINT then scaled with TWINABS [45] ( $\mathrm{Ag}(\mathrm{I})$ complex 33 was treated as a 3 component crystal) before Space group determination with XPREP [46]. The SHELXTL suites of programs $[46,47]$ were used for structure solution and OLEX2 for figures and refinement [48]. All non-hydrogen atoms were refined anisotropically but significant numbers were subject to restraints. The water molecules were treated as rigid bodies to find initial suitable $\mathrm{H}$ atom positions where close $\mathrm{H}---\mathrm{H}$ contacts were avoided and 
hydrogen bonding possibilities maximised and then their coordinates were fixed (using AFIX 1).

\subsection{Syntheses}

2.2.1. Synthesis of 2-(2-oxo-2H-chromen-substituted-yl)oxy acetic acidbased ligands $(\mathbf{1 2}-\mathbf{2 2})$

Firstly, the ethyl 2-(2-oxo-2H-chromen-substituted-yl)oxy acetate derivatives $(\mathbf{1}-\mathbf{1 1})$ were prepared by reaction of the appropriate substituted monohydroxy coumarin with ethyl 2-bromoacetate. The synthetic methodology, together with the analytical and spectroscopic data is given in Scheme S1, Table S1-S4 and Section S1 in Supplementary material. Then, the compounds obtained (1-11) were used as precursors for the synthesis of 2-(2-oxo- $2 H$-chromen-substitutedyl)oxy acetic acids (12-22) (Table 1) using the synthetic methodology described in Section S2. The analytical and IR spectral data for all the 2-(2-oxo-2H-chromen-substituted-yl)oxy acetic acid derivatives synthesized are shown in Table S5 (Supplementary material). Full ${ }^{1} \mathrm{H}$ and ${ }^{13} \mathrm{C}$ NMR spectral data are given in Tables S6 and S7, respectively (Supplementary material). The atom numbering system used for the assignment of the ${ }^{1} \mathrm{H}$ and ${ }^{13} \mathrm{C}$ NMR spectra is given in Table 1.

2.2.2. Synthesis of silver(I) complexes of 2-(2-oxo-2H-chromen-substituted-yl)oxy acetic acids (23-33)

A literature method was adopted for the synthesis of these complexes [21] and full synthetic details are given in Section S3 in Supplementary material. Selected bond lengths and bond angles obtained from crystal structure determination of complex $\mathbf{3 3}$ are presented in Table 2. Full analytical and IR, ${ }^{1} \mathrm{H},{ }^{13} \mathrm{C}$ NMR and UV-Vis spectroscopic data are presented in Section S3, Supplementary material with selected data for representative complexes given in Table S8 and Tables 3-6.

2.2.3. Synthesis of 1,10-phenanthroline adducts of silver(I) complexes of 2(2-oxo-2H-chromen-substituted-yl)oxy acetic acid-based ligands (34-44)

A literature method was adopted for the synthesis of these adducts [21]. All of the following reactions were carried out under dark conditions to obtain suitable complexes for structure elucidation studies. The experimental data recorded for phen adducts (34-44) are given in Section S4 in Supplementary material with selected data for representative complexes given in Tables 3-6.

\subsection{Computational details}

Molecular structures, vibrational (IR), NMR and absorption spectra calculations of the model $\mathrm{Ag}(\mathrm{I})$ complexes: $\mathrm{Ag}_{2}$ (C-3oxy-acet) ${ }_{2}, \mathrm{Ag}(\mathrm{C}$ 3oxy-acet)phen ${ }_{2}, \mathrm{Ag}_{2}$ (8acetyl-C-7oxy-acet) ${ }_{2}$ and $\mathrm{Ag}$ (8acetyl-C-7oxyacet)phen ${ }_{2}$ were carried out with DFT/TDDFT method using Gaussian09 program [49]. A bidentate oxylate bridging binding was simulated in $\mathrm{Ag}_{2}(\mathrm{~L})_{2}$ models as it was found in the X-ray determined structure of [Ag(8acetyl-C-7oxy-acet)] (33). Following the suggested formula for $\mathrm{Ag}(\mathrm{I})$-phen adducts, a possible monodentate oxalate bonding of the oxy-acetate coumarin and $\mathrm{N}, \mathrm{N}$-bidentate bonding of the two phen ligands were simulated for $\mathrm{Ag}\left(\mathrm{C}-3\right.$ oxy-acet) phen $_{2}$ and $\mathrm{Ag}$ (8acetyl-C7oxy-acet)phen 2 structures. For comparison, the corresponding

Table 1

Substituents, their positions, atom number assignment for ${ }^{1} \mathrm{H}$ and ${ }^{13} \mathrm{C}$ NMR spectra and abbreviations for 2-(2-oxo-2H-chromen-substituted-yl)oxy acetic acid ligands (12-22).

\begin{tabular}{|c|c|c|c|c|c|c|}
\hline IUPAC name of the compound/abbreviation (number) & $-\mathrm{R}^{3}$ & $-\mathrm{R}^{4}$ & $-\mathrm{R}^{5}$ & $-\mathrm{R}^{6}$ & $-\mathrm{R}^{7}$ & $-\mathrm{R}^{8}$ \\
\hline 2-[(2-Oxo-2H-chromen-3-yl)oxy]acetic acid/C-3oxy-acetH (12) & $\mathrm{OCH}_{2} \mathrm{COOH}$ & $\mathrm{H}$ & $\mathrm{H}$ & $\mathrm{H}$ & $\mathrm{H}$ & $\mathrm{H}$ \\
\hline $2-[(2-0 x o-2 H$-chromen-4-yl)oxy]acetic acid/C-4oxy-acetH (13) & $\mathrm{H}$ & $\mathrm{OCH}_{2} \mathrm{COOH}$ & $\mathrm{H}$ & $\mathrm{H}$ & $\mathrm{H}$ & $\mathrm{H}$ \\
\hline 2-[(6-Chloro-2-oxo-2H-chromen-4-yl)oxy]acetic acid/6Cl-C-4oxy-acetH (14) & $\mathrm{H}$ & $\mathrm{OCH}_{2} \mathrm{COOH}$ & $\mathrm{H}$ & $\mathrm{Cl}$ & $\mathrm{H}$ & $\mathrm{H}$ \\
\hline $2-[(2-O x o-2 H$-chromen-6-yl)oxy]acetic acid/C-6oxy-acetH (15) & $\mathrm{H}$ & $\mathrm{H}$ & $\mathrm{H}$ & $\mathrm{OCH}_{2} \mathrm{COOH}$ & $\mathrm{H}$ & $\mathrm{H}$ \\
\hline 2-[(4-Methyl-2-oxo-2H-chromen-6-yl)oxy]acetic acid/4Me-C-6oxy-acetH (16) & $\mathrm{H}$ & $\mathrm{CH}_{3}{ }^{*}$ & $\mathrm{H}$ & $\mathrm{OCH}_{2} \mathrm{COOH}$ & $\mathrm{H}$ & $\mathrm{H}$ \\
\hline 2-[(2-Oxo-2H-chromen-7-yl)oxy]acetic acid/C-7oxy-acetH (17) & $\mathrm{H}$ & $\mathrm{H}$ & $\mathrm{H}$ & $\mathrm{H}$ & $\mathrm{OCH}_{2} \mathrm{COOH}$ & $\mathrm{H}$ \\
\hline 2-[(4-Methyl-2-oxo-2H-chromen-7-yl)oxy]acetic acid/4Me-C-7oxy-acetH (18) & $\mathrm{H}$ & $\mathrm{CH}_{3}{ }^{*}$ & $\mathrm{H}$ & $\mathrm{H}$ & $\mathrm{OCH}_{2} \mathrm{COOH}$ & $\mathrm{H}$ \\
\hline 2-[(3,4,8-Trimethyl-2-oxo-2H-chromen-7-yl)oxy]acetic acid/3,4,8-triMe-C-7oxy-acetH (19) & $\mathrm{CH}_{3}{ }^{*}$ & $\mathrm{CH}_{3}^{\prime \prime}$ & $\mathrm{H}$ & $\mathrm{H}$ & $\mathrm{OCH}_{2} \mathrm{COOH}$ & $\mathrm{CH}_{3}^{\prime \prime \prime}$ \\
\hline 2-[(3-Chloro-4-methyl-2-oxo-2H-chromen-7-yl)oxy]acetic acid/3Cl-4Me-C-7oxy-acetH (20) & $\mathrm{Cl}$ & $\mathrm{CH}_{3}{ }^{*}$ & $\mathrm{H}$ & $\mathrm{H}$ & $\mathrm{OCH}_{2} \mathrm{COOH}$ & $\mathrm{H}$ \\
\hline 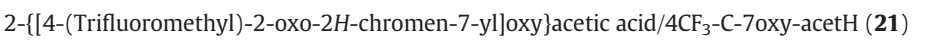 & $\mathrm{H}$ & $\mathrm{CF}_{3}{ }^{*}$ & $\mathrm{H}$ & $\mathrm{H}$ & $\mathrm{OCH}_{2} \mathrm{COOH}$ & $\mathrm{H}$ \\
\hline 2-[(8-Acetyl-2-oxo-2H-chromen-7-yl)oxy]acetic acid/8acetyl-C-7oxy-acetH (22) & $\mathrm{H}$ & $\mathrm{H}$ & $\mathrm{H}$ & $\mathrm{H}$ & $\mathrm{OCH}_{2} \mathrm{COOH}$ & $\mathrm{CH}_{3} \mathrm{CO}$ \\
\hline
\end{tabular}

$-\mathrm{OCH}_{2} \mathrm{COOH}=\mathrm{O}-\stackrel{11}{12}_{\mathrm{OH}}$

$-\mathrm{CH}_{3} \mathrm{CO}=\underset{\mathrm{H}_{3} \mathrm{C}-\mathrm{C}_{1}^{-}}{\stackrel{0}{10}}$

$\mathrm{CF}_{3}{ }^{*} / \mathrm{CH}_{3}{ }^{*}=$ assigned 15 to carbon and its protons. $\mathrm{CH}_{3}{ }^{\prime \prime}=$ assigned 16 to carbon and its protons. $\mathrm{CH}_{3}{ }^{\prime \prime \prime}=$ assigned 17 to carbon and its protons.

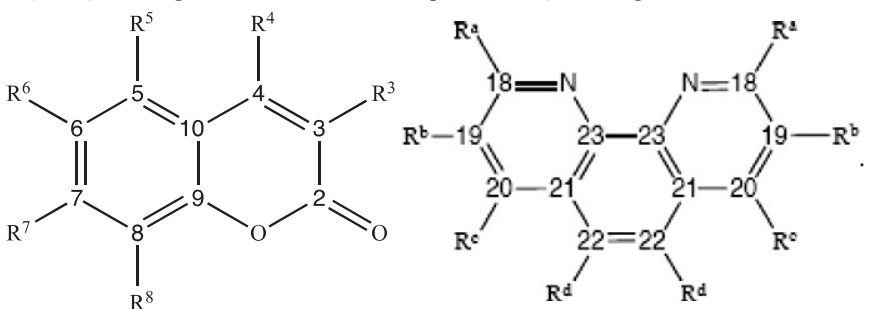

Atoms and substituents position numbering scheme for coumarin moiety and 1,10-phenanthroline $(\mathrm{R}=\mathrm{H})$. 
Table 2

Selected bond lengths $(\AA)$ and bond angles $\left({ }^{\circ}\right)$ of $[\operatorname{Ag}(8 a c e t y l-C-7 o x y-a c e t)](33)$ obtained from X-ray crystallographic analysis.

\begin{tabular}{|c|c|c|c|c|c|}
\hline \multicolumn{6}{|c|}{ Geometric parameters $\left(\AA,^{\circ}\right)$ for $(\operatorname{ag} 1)$} \\
\hline Ag1-Ag2 & $2.7490(16)$ & \multicolumn{2}{|l|}{$014-\mathrm{Ag} 1^{\mathrm{i}}$} & \multicolumn{2}{|l|}{$2.200(9)$} \\
\hline $\mathrm{Ag} 1-014^{\mathrm{i}}$ & $2.200(9)$ & $014-\mathrm{Ag}^{\text {iv }}$ & \multicolumn{3}{|c|}{$2.353(8)$} \\
\hline $\operatorname{Ag} 1-016^{\text {ii }}$ & $2.497(11)$ & $\mathrm{C} 15-\mathrm{C} 16$ & \multicolumn{3}{|c|}{$1.49(2)$} \\
\hline Ag1-028 & $2.126(9)$ & $\mathrm{C} 15-016$ & \multicolumn{3}{|c|}{$1.207(17)$} \\
\hline Ag1-O29 & $2.384(9)$ & $\mathrm{C} 15-017$ & \multicolumn{3}{|c|}{$1.47(2)$} \\
\hline $\mathrm{Ag} 2-\mathrm{O} 2$ & $2.500(10)$ & $015-A g 2^{i}$ & \multicolumn{3}{|c|}{$2.158(9)$} \\
\hline $\mathrm{Ag} 2-014^{\mathrm{iv}}$ & $2.353(8)$ & $\mathrm{C} 16-\mathrm{C} 17$ & \multicolumn{3}{|c|}{$1.41(2)$} \\
\hline $\mathrm{Ag} 2-015^{\mathrm{i}}$ & $2.158(9)$ & $\mathrm{C} 16-\mathrm{C} 25$ & \multicolumn{3}{|c|}{$1.358(19)$} \\
\hline Ag2-029 & $2.206(9)$ & $016-\mathrm{Ag} 1^{\mathrm{ii}}$ & \multicolumn{3}{|c|}{$2.497(11)$} \\
\hline $014^{\mathrm{i}}-\mathrm{Ag} 1-\mathrm{Ag} 2$ & $76.4(2)$ & $014^{\mathrm{i}}-\mathrm{Ag} 1-016^{\mathrm{ii}}$ & \multicolumn{3}{|c|}{$86.7(4)$} \\
\hline $014^{\mathrm{i}}-\mathrm{Ag} 1-029^{\mathrm{iii}}$ & $81.8(3)$ & $016^{\mathrm{ii}}-\mathrm{Ag} 1-\mathrm{Ag} 2$ & \multicolumn{3}{|c|}{$104.9(2)$} \\
\hline O28-Ag1-Ag2 & $88.3(2)$ & $028-\mathrm{Ag} 1-014^{\mathrm{i}}$ & \multicolumn{3}{|c|}{$162.6(3)$} \\
\hline $028-\mathrm{Ag} 1-016^{\mathrm{ii}}$ & $105.6(4)$ & $028-\mathrm{Ag} 1-029^{\mathrm{iii}}$ & \multicolumn{3}{|c|}{$107.6(4)$} \\
\hline $\mathrm{O} 29^{\mathrm{iii}}-\mathrm{Ag} 1-\mathrm{Ag} 2$ & $145.9(2)$ & $\mathrm{O} 29^{\mathrm{iii}}-\mathrm{Ag} 1-016^{\mathrm{ii}}$ & \multicolumn{3}{|c|}{$99.5(3)$} \\
\hline $\mathrm{O} 2-\mathrm{Ag} 2-\mathrm{Ag} 1$ & $121.6(2)$ & $014^{\mathrm{iv}}-\mathrm{Ag} 2-\mathrm{Ag} 1$ & \multicolumn{3}{|c|}{$149.3(2)$} \\
\hline $014^{\mathrm{iv}}-\mathrm{Ag} 2-\mathrm{O} 2$ & $83.8(3)$ & $015^{\mathrm{i}}-\mathrm{Ag} 2-\mathrm{Ag} 1$ & \multicolumn{3}{|c|}{$85.8(2)$} \\
\hline $015^{\mathrm{i}}-\mathrm{Ag} 2-02$ & $105.1(4)$ & $015^{\mathrm{i}}-\mathrm{Ag} 2-014^{\mathrm{iv}}$ & \multicolumn{3}{|c|}{$105.2(3)$} \\
\hline $015^{\mathrm{i}}-\mathrm{Ag} 2-029$ & $157.0(4)$ & O29-Ag2-Ag1 & \multicolumn{3}{|c|}{$77.7(2)$} \\
\hline O29-Ag2-02 & $97.2(4)$ & 029-Ag2-014 & \multicolumn{3}{|c|}{$82.4(3)$} \\
\hline Ag1i-014-Ag2iv & $98.2(3)$ & Ag2-029-Ag1v & \multicolumn{3}{|c|}{$97.1(4)$} \\
\hline \multicolumn{6}{|c|}{$\begin{array}{l}\text { Note: symmetry transformations used to generate equivalent atoms: (i) }-x+2,-y+2,-z+1 \text {; (ii) } x-1, y, z \text {; (iii) }-x+1,-y+1,-z+1 \text {; (iv) }-x+3,-y+2,-z+1 \text {; } \\
\quad \text { (v) } x+1, y, z \text {. }\end{array}$} \\
\hline \multicolumn{6}{|c|}{ Hydrogen-bond geometry $(\AA)$ for (ag1) } \\
\hline$D-\mathrm{H} \cdots A$ & $D-\mathrm{H}$ & $\mathrm{H} \cdots A$ & $D \cdots A$ & & $D-\mathrm{H} \cdots A$ \\
\hline $\mathrm{C} 7-\mathrm{H} 7 \cdots 019^{\mathrm{vi}}$ & 0.95 & 2.67 & & 143 \\
\hline $\mathrm{C} 9-\mathrm{H} 9 \cdots \mathrm{O} 19^{\mathrm{vi}}$ & 0.95 & 2.64 & \multicolumn{2}{|l|}{$3.46(2)$} & 144 \\
\hline $\mathrm{C} 20-\mathrm{H} 20 \cdots \mathrm{O} 5^{\mathrm{vii}}$ & 0.95 & 2.28 & \multicolumn{2}{|l|}{$3.23(2)$} & 177 \\
\hline $\mathrm{C} 23-\mathrm{H} 23 \cdots \mathrm{O} 1 \mathrm{~W}$ & 0.95 & 2.47 & \multicolumn{2}{|l|}{$3.285(14)$} & 144 \\
\hline $\mathrm{C} 23-\mathrm{H} 23 \cdots \mathrm{O} 2 \mathrm{~W}$ & 0.95 & 2.62 & \multicolumn{2}{|l|}{$3.494(16)$} & 153 \\
\hline $\mathrm{O} 1 W-\mathrm{H} 1 W A \cdots \mathrm{O} 2 W^{N}$ & 0.87 & 1.98 & \multicolumn{2}{|l|}{2.793} & 154.6 \\
\hline $\mathrm{O} 1 W-\mathrm{H} 1 W B \cdots \mathrm{O} 2 W$ & 0.87 & 1.99 & \multicolumn{2}{|l|}{2.611} & 127.4 \\
\hline
\end{tabular}

Symmetry codes: (v) $x+1, y, z$; (vi) $x+1, y+1, z$; (vii) $-x,-y+1,-z+2$.

calculations were performed for the isolated neutral ligands C-3oxyacetH (12) and 8acetyl-C-7oxy-acetH (22). Split valence plus polarization basis set $6-31 \mathrm{G}(\mathrm{d})$ was applied for the main group elements: for hydrogen atoms it is (4s)/[2s], for carbon and oxygen atoms it is (10s4p1d)/[3s2p1d]. To give a better description of the wave functions in the intermolecular region and hence to improve the estimation of the $\mathrm{Ag}(\mathrm{I})$ - coumarin ligand interactions, diffuse functions were added to the standard basis set (one $\mathrm{s}$ and one $\mathrm{p}$ set) for all $\mathrm{O}$ atoms as well as for the two acetoxy carbon, $\mathrm{C} 11$ and $\mathrm{C} 12$ atoms (see a scheme under Table 1). The combined basis set is denoted CB1. The computations using CB1 basis set were carried out with the Lee, Yang, and Parr correlation functional (LYP) [50] combined with Becke's three parameters exchange functional (B3) [51]. The adequacy of B3LYP method for prediction of conformational behaviour, geometry parameters and vibrational spectra of coumarin derivatives and their metal complexes was proven in our previous investigations $[52,53]$. The $\mathrm{Ag}(\mathrm{I})$ ion was calculated with the effective core potential (ECP) optimized by the StuttgartDresden group [54,55]. The small quasi-relativistic pseudopotential, ECP28MWB, was used for $\mathrm{Ag}(\mathrm{I})$ in combination with its optimized valence basis set (8s7p6d)/[6s5p3d]. The small core (RECPs) for the $\mathrm{Ag}(\mathrm{I})$ centre considers explicitly 19 valence electrons $\left(4 s^{2} 4 p^{6} 4 d^{10} 5 s^{1}\right)$, whereas 28 core electrons ([Ar] $3 \mathrm{~d}^{10}$ shells) are replaced by the pseudopotential.

Full geometry optimizations of all the molecular systems were carried out without symmetry constraint. The minima on the potential energy surfaces were qualified by the absence of negative eigenvalues in the diagonalized Hessian matrix, giving imaginary normal vibrational mode. The projection of the internal coordinates onto each normal mode in terms of percentage relative weights was computed as implemented in Gaussian09. Each normal mode is described on the basis of the largest percentage value of the total displacement vector magnitude. In addition, the vibrational modes have been analysed by visual inspection of the modes animated using the ChemCraft program [56]. The ${ }^{1} \mathrm{H}$ and ${ }^{13} \mathrm{C}$
NMR chemical shift calculations of the model compounds 12, 22, 23, 33, and 34 were performed in DMSO at B3LYP/6-31 + G(d,p) level. The absolute isotropic magnetic shielding constants $\left(\sigma_{\mathrm{i}}\right)$ were used to obtain the chemical shifts $\left(\delta_{\mathrm{i}}=\sigma_{\mathrm{TMS}}-\sigma_{\mathrm{i}}\right)$ for $\mathrm{C}$ and $\mathrm{H}$ atoms by referring to the standard compound, TMS. The UV-Vis absorption spectra of the ligands and their $\mathrm{Ag}(\mathrm{I})$ complexes were simulated in the region 200$400 \mathrm{~nm}$ by means of vertical excitation energy calculations (of singlet excited states) in DMSO using TDDFT method and B3LYP/CB1 level. NMR and UV-Vis spectra calculations in DMSO were performed for the optimized geometries in the same solvent. A non-equilibrium implementation of the Polarisable Continuum Model (PCM) using the integral equation formalism variant (IEFPCM) was applied to simulate the solvent [57-59].

\subsection{Antimicrobial studies}

The ligands (12-22), $\mathrm{Ag}(\mathrm{I})$ complexes (23-33), phenanthroline adducts (34-44) and commercially available drugs, gentamycin and vancomycin, were screened for their antimicrobial activity. S. aureus (NCIMB 12702) was obtained from the National Collection of Industrial, Marine and Food. MRSA strain ATCC4300 and P. aeruginosa strain ATCC 27853 were obtained from the American Type Culture Collection. P. aeruginosa were cultured in Luria Bertani (LB) broth (Sigma) while MRSA was cultured in nutrient broth. Bacteria were stored in broth with $20 \%$ glycerol at $-80{ }^{\circ} \mathrm{C}$ and passaged twice on agar plate (LB agar, Trypticase Soy agar (TSA) or nutrient agar respectively) before being used in an experiment. $\mathrm{MIC}_{50}$ were determined by broth microdilution. Stock solutions of each compound to be tested were prepared in DMSO and serially diluted in triplicate using broth $(100 \mu \mathrm{l} /$ well) at a concentration range of $0.195-200 \mu \mathrm{M}$ on microtitre plates, after which the final concentration of DMSO in the cell suspension was not $>1 \%$. Overnight cultures $(10 \mathrm{ml})$ of bacterial strains were inoculated in broth $(100 \mathrm{ml})$ and incubated at $37^{\circ} \mathrm{C}$ with agitation, optical 
Table 3

Selected experimental and calculated* IR frequencies $\left(\nu, \mathrm{cm}^{-1}\right)$ of ligands and their silver(I) complexes and phen adducts.

\begin{tabular}{|c|c|c|c|c|c|}
\hline Compound & $v C-\mathrm{H}$ & $v \mathrm{C}=\mathrm{O}_{\text {coumarin }} / v \mathrm{C}=\mathrm{O}_{\text {acid }}$ & $v_{\text {asym }}(\mathrm{OCO})$ & $v_{\text {sym }}(\mathrm{OCO})$ & $\Delta v(\mathrm{OCO})$ \\
\hline C-3oxy-acetH (12) & 3052 v, $2997 \mathrm{vw}$ & $\begin{array}{l}1713 \mathrm{vs} / 1736 \mathrm{~s} \\
(1711 / 1761)^{\text {calc* }}\end{array}$ & - & - & - \\
\hline$[\mathrm{Ag}(\mathrm{C}-30 x y-a c e t)](\mathbf{2 3})$ & 3055 v, $2980 \mathrm{vw}$ & 1721 vs $(1718)^{\text {calc }}$ & $\begin{array}{l}1584 \mathrm{~s} \\
(1566)^{\text {calc }}\end{array}$ & $\begin{array}{l}1402 \mathrm{~m} \\
(1392)^{\text {calc }}\end{array}$ & $\begin{array}{l}182 \\
(174)^{\text {calc }}\end{array}$ \\
\hline [Ag(C-3oxy-acet)phen2] (34) & $3067 v$ & 1718 vs $(1724)^{\text {calc }}$ & $\begin{array}{l}1618 \text { vs } \\
(1624)^{\text {calc }}\end{array}$ & $\begin{array}{l}1383 \mathrm{~m} \\
(1367)^{\mathrm{calc}(/ \mathrm{C}-\mathrm{O}}\end{array}$ & $\begin{array}{l}235 \\
(257)^{\text {calc }}\end{array}$ \\
\hline 8acetyl-C-7oxy-acetH (22) & $3071 v, 2964 v w$ & $\begin{array}{l}1692 \mathrm{~s} / 1760 \mathrm{~m} \\
(1739 / 1780)^{\text {calc }}\end{array}$ & - & - & - \\
\hline [Ag(8acetyl-C-7oxy-acet)] (33) & $3074 v, 2927 v w$ & $1721 \mathrm{~s}(1739)^{\text {calc }}$ & $\begin{array}{l}1570 \mathrm{~m} \\
(1578)^{\text {calc }}\end{array}$ & $\begin{array}{l}1405 \mathrm{~m} \\
(1375)^{\text {calc }}\end{array}$ & $\begin{array}{l}165 \\
(203)^{\text {calc }}\end{array}$ \\
\hline [Ag(8acetyl-C-7oxy-acet)phen 2 ] (44) & $3055 v$ & $1723 \mathrm{~s}(1727)^{\mathrm{calc}}$ & $\begin{array}{l}1622 \mathrm{~s} \\
(1622)^{\text {calc }}\end{array}$ & $\begin{array}{l}1400 \mathrm{~m} \\
(1352)^{\text {calc }}\end{array}$ & $\begin{array}{l}(222) \\
(270)^{\text {calc }}\end{array}$ \\
\hline
\end{tabular}

All IR spectra were run as KBr discs. * calculated frequencies with DFT/B3LYP/CB1 method, scaled by factor 0.96;

CB1 basis set - see the Computational details.

overl - overlapped, vs - very strong, s - strong, m - medium, w - weak, vw - very weak.

density at $600 \mathrm{~nm}\left(\mathrm{OD}_{600}\right)$ was measured and strains were then diluted to $1 \times 10^{6} \mathrm{CFU} / \mathrm{ml}$ and seeded at $100 \mu \mathrm{l} /$ well in microtitre well plates. Bacteria were also treated with a solvent control (0.5\% DMSO) in control wells. Following $24 \mathrm{~h}$ incubation the absorbance was read in a microtitre plate reader. Each compound was screened at each concentration at least in triplicate and three independent experiments were carried out.

In this study, the ligands, their $\mathrm{Ag}(\mathrm{I})$ complexes and 1,10phenanthroline adducts were tested for anti-Candida activity using a broth microdilution susceptibility protocol established by the National Committee for Clinical Laboratory Standards (NCCLS), document M27A2 with slight modifications. The M27-A2 method was altered by substituting antibiotic medium 3 (Oxoid Ltd.) for RPMI 1640 medium [60]. All of the test compounds were prepared in $2 \%$ DMSO solution as the compounds were soluble only in DMSO. This solvent system is frequently used for antifungal testing of drugs. However, complexes 35, 36, 41 and $\mathbf{4 2}$ did not dissolve well in 2\% DMSO and therefore these were tested as suspensions. The maximum concentration of the DMSO, after serial dilution, in the test wells was $0.5 \%$. The inhibitory effect of DMSO on the growth of $C$. albicans was also examined and it was shown that $0.5 \%$ DMSO did not affect the growth of this particular strain (ATCC 10231) of $C$. albicans. However, the effect of DMSO concentration on the growth of the Candida species can be dependent on the strain origin and hence different strains of microbes can have different tolerances to DMSO. These results indicated that the maximum final concentration of DMSO that can be used in the assay was ca. $1 \%$. The ligands, complexes and a commercially available antifungal drug, Amphothericin B were tested against $C$. albicans (ATCC 10231). The screening was carried out according to the broth microdilution reference method [60].

\subsection{MTT assay}

The activity of the ligands and their complexes was assessed using cancer cell lines: HepG2 cell line, which is a liver-derived cell line, and A498, which is a renal cell line. Testing was carried out using the methylthiazolyldiphenyl-tetrazolium bromide (MTT) assay following $96 \mathrm{~h}$ exposure of the cells [61]. This method is based on the reduction of the tetrazolium salt MTT (3-(4,5-dimethylthiazolyl-2)-2,5-diphenyltetrazolium bromide) into a crystalline blue formazan product by the cellular oxidoreductases of viable cells. The resultant formazan crystal formation is proportional to the number of viable cells. The following procedure was used to test the silver complexes and mitoxantrone. Cells were seeded at $4 \times 10^{5}$ cells $/ \mathrm{ml}$ in 96 -well plates and incubated at $37^{\circ} \mathrm{C}$ in $5 \% \mathrm{CO}_{2}$ for $96 \mathrm{~h}$. Cells were treated with a range of concentrations of the test compounds, in triplicate, from 0.2 to $200 \mu \mathrm{M}$ or with a solvent control $(0.5 \%$ DMSO) in complete medium. After $96 \mathrm{~h}$ incubation, the cells were assayed by the addition of one-tenth $(20 \mu \mathrm{l})$ of the culture volume with MTT $(5 \mathrm{mg} / \mathrm{ml})$ in $0.1 \mathrm{M}$ phosphate-buffered saline (PBS), pH 7.4, at
$37{ }^{\circ} \mathrm{C}$ in a humid atmosphere with $5 \% \mathrm{CO}_{2}$ for $4 \mathrm{~h}$. The medium was then gently aspirated from test cultures and $100 \mu \mathrm{l}$ of DMSO was added to each well. The plates were then shaken for 2 min and the absorbance was read at $550 \mathrm{~nm}$ in a Varioscan plate reader. The $\mathrm{IC}_{50}$ value was defined as the concentration of test compound required to reduce the absorbance of the MTT-formazan crystals by $50 \%$, indicating $50 \%$ reduction in cellular activity.

\subsection{DNA binding studies}

The competitive ethidium bromide (EtBr) displacement studies involved the preparation of a working solution containing $1 \mu \mathrm{M}$ calf thymus DNA (CT-DNA) $\left(\varepsilon 260=12,824 \mathrm{M}(\mathrm{bp})^{-1} \mathrm{~cm}^{-1}\right)$ [bp = base pair] along with $1.26 \mu \mathrm{M} \mathrm{EtBr}$ at neutral $\mathrm{pH}$ in $N$-[tris(hydroxymethyl)methyl]-2aminoethanesulfonic acid (TES) buffer (10 mM TES, $0.10 \mathrm{mM}$ disodium ethylenediamine tetraacetate $\left.\left(\mathrm{Na}_{2} \mathrm{EDTA}\right), \mathrm{pH}=7\right)$. Stock solutions of complex 31 and controls were prepared at $2 \mathrm{mM}$ in 100\% DMSO. Two $\mathrm{ml}$ of DNA-Et solution were placed in a $10 \mathrm{~mm}$ quartz cuvette $(3 \mathrm{ml}$ ) and positioned in a temperature controlled $\left(20^{\circ} \mathrm{C}\right)$ spectrofluorometer. Excitation and emission wavelengths were set to 545 and $595 \mathrm{~nm}$, respectively. After thermal equilibrium was established the emission and excitation slits were changed to give a fluorescence reading of 50 arbitrary units with measurements being recorded over a $20 \mathrm{~s}$ interval. An aliquot of complex or drug solution was taken (1-20 $\mu \mathrm{l})$, added to the cuvette and after equilibration the fluorescence reading was recorded. Repeated aliquots were added until the fluorescence was $30-40 \%$ of the initial control or the capacity of the $10 \mathrm{~mm}$ quartz cuvette $(3 \mathrm{ml}$ ) to hold $>1000 \mu \mathrm{l}$ of sample was exceeded. Triplicate titrations were performed and the apparent binding constants were calculated using Kapp $=\mathrm{Ke} \times 1.26$ / $\mathrm{C} 50$ where $\mathrm{Ke}=9.50 \times 10^{6} \mathrm{M}(\mathrm{bp})^{-1}$ and 1.26 is the concentration of $\mathrm{EtBr}$ in $\mu \mathrm{M}$ [62].

\subsection{Determination of nuclease activity}

The nuclease activity of complex $\mathbf{3 1}$ and controls was determined by adopting the following method [62]. Reactions were carried out in a total volume of $20 \mu \mathrm{l}$ in $0.10 \mathrm{M}$ cacodylate buffer $(\mathrm{pH}=6)$ with 50 $0.50 \mu \mathrm{M}$ of complex, which were initially prepared in DMF, then diluted in buffer, with $1 \mu \mathrm{l}$ of $0.25 \mu \mathrm{g} / \mu \mathrm{l}$ pBR322 DNA (Roche). Samples were incubated for $5 \mathrm{~h}$ at $37^{\circ} \mathrm{C}$ (with and without an added reductant). Quench buffer ( $3 \mu \mathrm{l}$; $0.25 \%$ bromophenol blue, $0.25 \%$ xylene cyanole and $30 \%$ glycerol) was then added and samples were loaded onto agarose gel (1\%) containing $1.50 \mu \mathrm{l} / 100 \mathrm{ml}$ of solution of GelRedTM (10,000 X). Electrophoresis was completed at $80 \mathrm{~V}$ for $2 \mathrm{~h}$ in $1 \times$ TAE buffer (Tris-Acetate-EDTA). 
Table 4

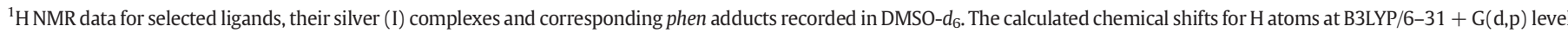
are given in parentheses.

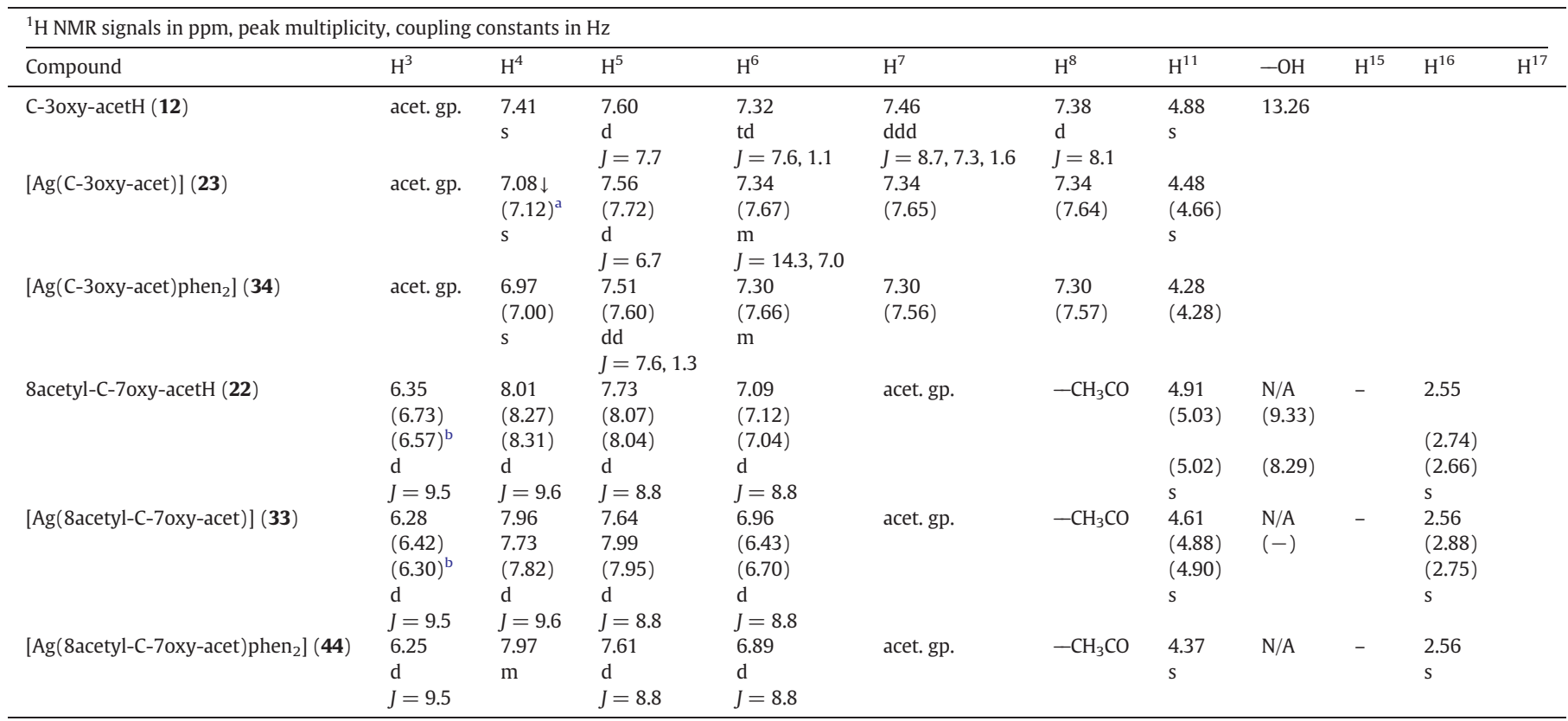

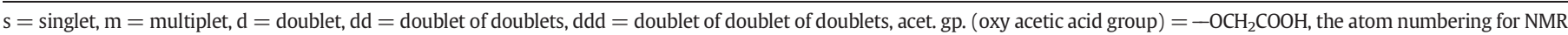
signals assignment is given in Table 1 .

${ }^{\text {a }}$ The ${ }^{1} \mathrm{H}$ NMR calculations at (B3LYP/6-31 + G(d,p) level) suggested cis- $\mathrm{Ag}_{2}$ (C-3oxy-acet $)_{2}$ structure.

b ${ }^{1} \mathrm{H}$ NMR calculations at B3LYP/6-31++G(2d,p) level of theory for comparison.

\subsection{Determination of SOD mimetic ability}

The SOD mimetic activities of the metal complex $\mathbf{3 1}$ and controls were studied by following the change in absorbance at $\lambda=550 \mathrm{~nm}$ during the reduction of nitroblue tetrazolium (NBT) to blue formazan in the presence of the tested complex. The assay was run at $\mathrm{pH} 7.80$ in a cuvette containing $3 \mathrm{ml}$ of the reaction mixture. The reaction mixture consisted of a double distilled water solution of $50 \mu \mathrm{M}$ xanthine, $100 \mu \mathrm{M}$ NBT and $50 \mathrm{mM}$ PBS. A flux of the superoxide radicals was established by the addition of $20 \mu$ of diluted xanthine oxidase enzyme to the cuvette. Reduction of NBT by $\mathrm{O}_{2}^{-}$. was thermostatically controlled for three minutes at $25{ }^{\circ} \mathrm{C}$ and resulted in a $0.02 / \mathrm{min}$ change in absorbance at $\lambda=550 \mathrm{~nm}$. This corresponded to a flux of $1 \mu \mathrm{M} \mathrm{O} \mathrm{O}_{2}^{-} / \mathrm{min}$. After the $\mathrm{O}_{2}^{-}$. flux was established, the quantitative reduction of NBT to blue formazan by $\mathrm{O}_{2}^{-}$. was followed spectrophotometrically at $550 \mathrm{~nm}$, in the presence of the tested complex.

\section{Results and discussion}

\subsection{Synthesis and characterisation of silver(I) complexes (23-33) and their phen adducts (34-44)}

Firstly, the ethyl 2-(2-oxo-2H-chromen-substituted-yl)oxy acetate derivatives (1-11) were prepared by reaction of the appropriate substituted monohydroxy coumarin with ethyl 2-bromoacetate. Then, the compounds obtained were used as precursors for the synthesis of 2(2-oxo-2H-chromen-substituted-yl)oxy acetic acids (12-22) (Table 1) by acid hydrolysis in acetone: water (40:60) mixture (Scheme S1 and

Table 5

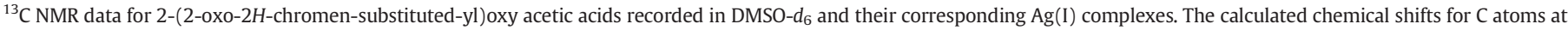
B3LYP/6-31 + G(d,p) are given in parenthesis.

\begin{tabular}{|c|c|c|c|c|c|c|c|c|c|c|c|c|c|c|}
\hline \multicolumn{15}{|l|}{${ }^{13} \mathrm{C}$ NMR signals in $\mathrm{ppm}$} \\
\hline Compound & $C^{2}$ & $\mathrm{C}^{3}$ & $C^{4}$ & $C^{5}$ & $C^{6}$ & $C^{7}$ & $C^{8}$ & $\mathrm{C}^{9}$ & $\mathrm{C}^{10}$ & $\mathrm{C}^{11}$ & $C^{12}$ & $C^{15}$ & $C^{16}$ & $C^{17}$ \\
\hline C-3oxy-acetH (12) & 156.4 & 142.2 & 115.1 & 127.1 & 124.8 & 128.8 & 115.7 & 149.2 & 119.5 & 65.1 & 169.0 & - & - & - \\
\hline$[\mathrm{Ag}(\mathrm{C}-30 x y$-acet $)](\mathbf{2 3})$ & $\begin{array}{l}156.6 \\
(156.7)^{\mathrm{a}}\end{array}$ & $\begin{array}{l}143.1 \uparrow \\
(140.4)\end{array}$ & $\begin{array}{l}113.8 \downarrow \\
(114.6)\end{array}$ & $\begin{array}{l}126.5 \\
(128.4)\end{array}$ & $\begin{array}{l}124.4 \\
(119.2)\end{array}$ & $\begin{array}{l}127.9 \\
(126.0)\end{array}$ & $\begin{array}{l}115.3 \\
(112.7)\end{array}$ & $\begin{array}{l}148.8 \\
(150.3)\end{array}$ & $\begin{array}{l}119.8 \\
(119.2)\end{array}$ & $\begin{array}{l}67.9 \uparrow \\
(68.6)\end{array}$ & $\begin{array}{l}169.6 \\
(170.5)\end{array}$ & & & \\
\hline$\left[\mathrm{Ag}(\mathrm{C}-3\right.$ oxy-acet$)$ phen $\left._{2}\right](\mathbf{3 4})$ & $\begin{array}{l}156.9 \\
(156.9)\end{array}$ & $\begin{array}{l}143.4 \\
(140.7)\end{array}$ & $\begin{array}{l}113.9 \\
(114.0)\end{array}$ & $\begin{array}{l}126.6 \\
(125.0)\end{array}$ & $\begin{array}{l}124.5 \\
(120.8)\end{array}$ & $\begin{array}{l}127.8 \\
(125.5)\end{array}$ & $\begin{array}{l}115.5 \\
(112.5)\end{array}$ & $\begin{array}{l}148.7 \\
(149.8)\end{array}$ & $\begin{array}{l}120.1 \\
(119.5)\end{array}$ & $\begin{array}{l}68.5 \\
(69.0)\end{array}$ & $\begin{array}{l}168.3 \\
(167.9)\end{array}$ & & & \\
\hline 8acetyl-C-7oxy-acetH (22) & $\begin{array}{l}159.4 \\
(160.1) \\
(161.2)^{\mathrm{C}}\end{array}$ & $\begin{array}{l}113.4 \\
(109.7) \\
(110.0)\end{array}$ & $\begin{array}{l}144.2 \\
(145.2) \\
(144.4)\end{array}$ & $\begin{array}{l}130.3 \\
(129.5) \\
(129.2)\end{array}$ & $\begin{array}{l}109.3 \\
(106.1) \\
(106.6)\end{array}$ & $\begin{array}{l}156.8 \\
155.2) \\
(155.5)\end{array}$ & $\begin{array}{l}118.7 \\
(117.9) \\
(116.8)\end{array}$ & $\begin{array}{l}150.3 \\
(151.3) \\
(150.3)\end{array}$ & $\begin{array}{l}113.1 \\
(113.5) \\
(113.5)\end{array}$ & $\begin{array}{l}65.2 \\
(66.6) \\
(64.8)\end{array}$ & $\begin{array}{l}169.6 \\
(168.4) \\
(170.1)\end{array}$ & $\begin{array}{l}199.0 \\
(206.9) \\
(206.4)\end{array}$ & $\begin{array}{l}32.2 \\
(35.7) \\
(33.5)\end{array}$ & \\
\hline [Ag(8acetyl-C-7oxy-acet)] (33) & $\begin{array}{l}159.3 \\
(159.9) \\
(160.5)^{d}\end{array}$ & $\begin{array}{l}109.5 \\
(107.9) \\
(108.8)\end{array}$ & $\begin{array}{l}144.0 \\
(144.4) \\
(143.8)\end{array}$ & $\begin{array}{l}129.7 \\
(127.4) \\
(128.5)\end{array}$ & $\begin{array}{l}112.5 \\
(109.9) \\
(110.3)\end{array}$ & $\begin{array}{l}158.0 \\
(156.8) \\
(160.0)\end{array}$ & $\begin{array}{l}118.5 \\
(116.5) \\
(115.6)\end{array}$ & $\begin{array}{l}150.1 \\
150.4 \\
(149.6)\end{array}$ & $\begin{array}{l}112.1 \\
(111.1) \\
(111.2)\end{array}$ & $\begin{array}{l}67.9 \\
(68.0) \\
(68.6)\end{array}$ & $\begin{array}{l}170.5 \\
(171.2) \\
(172.5)\end{array}$ & $\begin{array}{l}198.9 \\
(206.2) \\
(205.7)\end{array}$ & $\begin{array}{l}31.9 \\
(33.6) \\
(33.3)\end{array}$ & \\
\hline [Ag(8acetyl-C-7oxy-acet)phen 2$](44)$ & 159.7 & 109.9 & 144.4 & 129.8 & 112.2 & 158.9 & 118.3 & 150.2 & 111.8 & 68.6 & 168.7 & 199.7 & 32.1 & \\
\hline
\end{tabular}

Coupling constants in $\mathrm{Hz}, \mathrm{q}=$ quartet, the atom numbering for NMR signals assignment is given in Table S1.

a The ${ }^{13} \mathrm{C}$ NMR calculations at $(\mathrm{B} 3 \mathrm{LYP} / 6-31+\mathrm{G}(\mathrm{d}, \mathrm{p})$ level $)$ suggested cis- $\mathrm{Ag}_{2}(\mathrm{C} \text {-3oxy-acet })_{2}$ structure.

${ }^{\mathrm{b}}$ Ref. [70].

c Signals for phen ligands are given in Supplementary material.

d ${ }^{13} \mathrm{C}$ NMR calculations at B3LYP/6-31++G(2d,p) level for comparison. 
Table 6

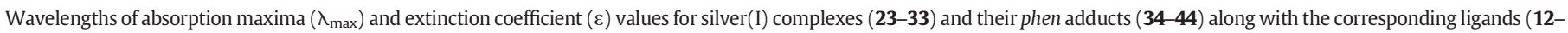
22). The calculated vertical excitation energies at TDDFT/B3LYP/CB1 are given for comparison.

\begin{tabular}{|c|c|c|c|c|c|c|c|c|c|c|c|}
\hline \multicolumn{4}{|c|}{ Ligand } & \multicolumn{4}{|c|}{ Silver(I) complex } & \multicolumn{4}{|c|}{ Silver(I)-phen adduct } \\
\hline & $\begin{array}{l}\lambda_{\max }(\varepsilon) \\
\mathrm{nm}\left(\mathrm{M}^{-1} \mathrm{~cm}^{-1}\right)\end{array}$ & $\begin{array}{l}\Delta \mathrm{E} \text { (osc.str) } \\
\mathrm{nm}\end{array}$ & Assign & & $\begin{array}{l}\lambda_{\max }(\varepsilon) \\
\mathrm{nm}\left(\mathrm{M}^{-1} \mathrm{~cm}^{-1}\right)\end{array}$ & $\begin{array}{l}\Delta \mathrm{E}(\text { osc.str }) \\
\mathrm{nm}\end{array}$ & Assign & & $\begin{array}{l}\lambda_{\max }(\varepsilon) \\
\mathrm{nm}\left(\mathrm{M}^{-1} \mathrm{~cm}^{-1}\right)\end{array}$ & $\begin{array}{l}\Delta \mathrm{E} \text { (osc.str) } \\
\mathrm{nm}\end{array}$ & Assign \\
\hline \multirow[t]{5}{*}{12} & & & & 23 & & & & 34 & 325 (14080) & $325(0.08)$ & $\mathrm{Ag}_{\text {sd, }} \mathrm{L}$, phen-phen $\left(\pi^{*}\right)$ \\
\hline & $310(14220)$ & $303(0.44)$ & $\pi-\pi^{*}$ & & $310(12640)$ & $306(0.92)^{* a}$ & $\mathrm{~L}(\pi)-\mathrm{L}\left(\pi^{*}\right)$ & & 305 (23120) & $306(0.49)$ & $\mathrm{L}(\pi)-\mathrm{L}\left(\pi^{*}\right)$ \\
\hline & & & & & & $305(0.08)$ & $\mathrm{L}(\pi)-\mathrm{L}\left(\pi^{*}\right)$ & & & $256(0.88)$ & phen $(\pi)$-phen $\left(\pi^{*}\right)$ \\
\hline & $\sim 280(18220)$ & $285(0.03)$ & $\pi-\pi^{*}$ & & $\sim 290$ & $283(0.03)$ & $\mathrm{L}(\pi)-\mathrm{L}\left(\pi^{*}\right)$ & & & & \\
\hline & & $235(0.04)$ & $\pi-\pi^{*}$ & & $(11600)$ & $235(0.15)$ & $\mathrm{L}(\pi)-\mathrm{L}\left(\pi^{*}\right)$ & & & & \\
\hline \multirow[t]{5}{*}{22} & $320(17220)$ & $310(0.54)^{\mathrm{b}}$ & $\pi-\pi^{*}$ & 33 & $320(13280)$ & $313(1.12)$ & $\mathrm{L}(\pi)-\mathrm{L}\left(\pi^{*}\right)$ & 44 & 335 (17820) & & \\
\hline & $290(14780)$ & $284(0.01)$ & $\pi-\pi^{*}$ & & 285 & $293(0.03)$ & $\mathrm{L}(\pi)-\mathrm{L}\left(\pi^{*}\right)$ & & & & \\
\hline & - & - & - & & 265 & $277(0.03)$ & $\mathrm{L}(\pi)-\mathrm{L}\left(\pi^{*}\right)$ & & & & \\
\hline & & & & & & $265(0.04)$ & $\mathrm{L}(\pi)-\mathrm{Ag}_{\mathrm{sd}}, \mathrm{O}$ & & & & \\
\hline & 240 & $240(0.07)$ & $\pi-\pi^{*}$ & & 240 & $238(0.12)$ & $\mathrm{L}(\pi)-\mathrm{L}\left(\pi^{*}\right)$ & & & & \\
\hline \multirow[t]{3}{*}{13} & $320(5760)$ & & & $24^{*}$ & $320(4420)$ & & & 35 & $320(5480)$ & & \\
\hline & $305(10680)$ & & & & $305(8300)$ & & & & $295(21060)$ & & \\
\hline & $280(17080)$ & & & & $280(11860)$ & & & & & & \\
\hline \multirow[t]{3}{*}{14} & $325(5520)$ & & & 25 & $325(5240)$ & & & $36^{*}$ & 325 (7120) & & \\
\hline & $310(7540)$ & & & & $310(7060)$ & & & & 315 (9580) & & \\
\hline & $280(15080)$ & & & & 285 (9200) & & & & & & \\
\hline \multirow[t]{2}{*}{15} & $340(4260)$ & & & 26 & $350(3800)$ & & & 37 & $345(4100)$ & & \\
\hline & $280(17280)$ & & & & $280(13360)$ & & & & & & \\
\hline \multirow[t]{2}{*}{16} & $335(6360)$ & & & 27 & $345(3940)$ & & & $38^{*}$ & $340(4940)$ & & \\
\hline & 275 (20900) & & & & $280(13720)$ & & & & & & \\
\hline 17 & $320(15400)$ & & & 28 & 325 (17120) & & & 39 & 325 (17540) & & \\
\hline \multirow[t]{2}{*}{18} & $320(17560)$ & & & 29 & 325 (16460) & & & 40 & 325 (19720) & & \\
\hline & $285(13760)$ & & & & & & & & & & \\
\hline 19 & 315 (15540) & & & $30^{*}$ & 325 (16940) & & & 41 & 335 (15600) & & \\
\hline 20 & $325(17780)$ & & & 31 & 335 (15580) & & & $42^{*}$ & 340 (19320) & & \\
\hline 21 & $330(14200)$ & & & $32^{*}$ & 345 (13200) & & & 43 & 345 (15900) & & \\
\hline
\end{tabular}

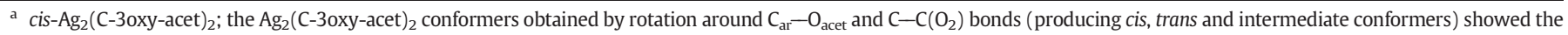
same UV-Vis spectra.

b Open ligand form as it is shown in Fig. S2.

Section S2 in Supplementary material). The analytical, IR, ${ }^{1} \mathrm{H}$ and ${ }^{13} \mathrm{C}$ NMR spectroscopic data for all ethyl coumarinyloxyacetates (1-11) and coumarin oxyacetic acid-based ligands synthesized (12-22) are given in Supplementary material (Tables S1-S4 and S5-S7, respectively).

The reaction methodology for the synthesis of 2-[(2-oxo-2H-chromen-substituted-yl)oxy]acetic acid-based silver(I) complexes and its phen adducts is presented in Scheme 1. The silver(I) complexes (2333) were synthesized by deprotonation of the 2-(2-oxo- $2 \mathrm{H}$-chromensubstituted-yl)oxy acetic acid-based ligands (12-22) using a stoichiometric amount of sodium hydrogen carbonate and then adding a stoichiometric amount of silver(I) nitrate. Further, the silver(I)-phen adducts (34-44) were obtained by stirring of the silver(I) complexes (23-33) with 1,10-phenanthroline in absolute ethanol.

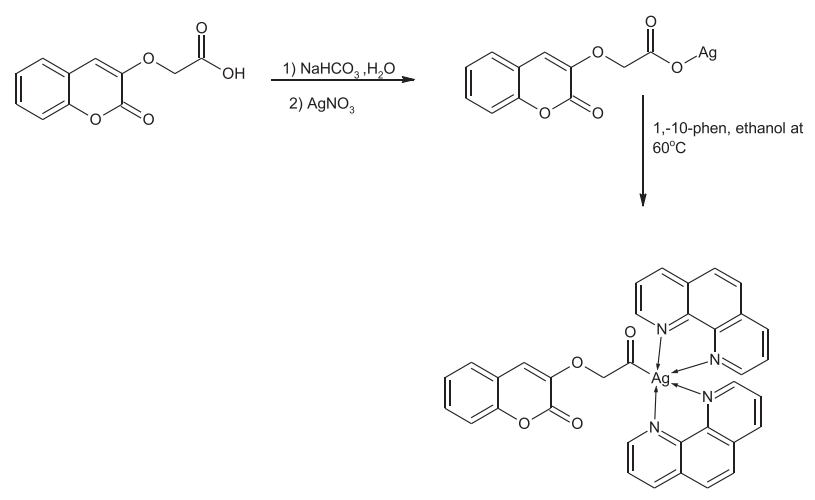

Scheme 1. General reaction scheme for the synthesis of 2-[(2-oxo-2H-chromen-3yl)oxy]acetic acid-based silver(I) complex and its phen adduct.
All of the synthesized silver(I) complexes and their phen adducts were characterised by microanalysis and atomic absorption spectroscopy, thermogravimetric analysis, conductivity measurements, UV-Vis, IR, ${ }^{1} \mathrm{H}$ and ${ }^{13} \mathrm{C}$ NMR spectroscopies, decomposition temperatures, and in one case (33), by X-ray diffraction analysis.

Microanalytical and atomic absorption spectroscopic data (Table S8) revealed that the silver(I) complexes 23-33 have a 1:1 metal-to-ligand ratio. The silver(I)-phen adducts 34-44 exhibited a 1:1:2 ratio between metal, ligand and phen, respectively. Complexes 24, 26, 27, 31 and 32 also showed the presence of water molecules and the relative amounts of water present was determined by thermogravimetric analysis (Fig. S1, Supplementary material). Unfortunately the addition of the oxyacetate moiety to the coumarin nucleus did not increase significantly the solubility of the silver(I) complexes except in the case of complex [Ag(8acetyl-C-7oxy-acet)] 33, which was sparingly soluble in water at ambient temperature. More surprisingly, the formation of the phen adducts, even allowing for the presence of two additional phen ligands in each silver(I) complex, also did not improve solubility with all of the coordination compounds being only soluble in DMSO. The observed conductivity values for the silver(I) complexes and the corresponding phen adducts at $25^{\circ} \mathrm{C}$ were in the range 0.43 to $1.95 \mathrm{Scm}^{2} \mathrm{~mol}^{-1}$ and at $37{ }^{\circ} \mathrm{C}$ were in the range 1.32 to $2.13 \mathrm{Scm}^{2} \mathrm{~mol}^{-1}$. These values at both temperatures were too low to account for any dissociation of the metal complexes and adducts in DMSO. Hence, these complexes and their phen adducts were regarded as non-electrolyte in nature and are considered to be similar to other coumarin-based complexes [44,63-66]. A number of attempts were made to grow crystals suitable for X-ray diffraction analysis for all the silver(I) complexes and their phen adducts prepared in this study. Unfortunately, crystals could not be obtained except for the silver(I) complex [Ag(8acetyl-C-7oxy-acet)] (33). 


\subsubsection{Crystal structure of $[\mathrm{Ag}(8 a c e t y l-C-7 o x y$-acet) $]$ (33)}

Crystal structure data and structure refinement details are given in Supplementary material (Tables S9-S11). Selected bond lengths and bond angles are presented in Table 2 . The crystal structure, together with the atom numbering scheme and the crystal packing structure diagram are shown in Fig. 1 and Fig. 2, respectively.

There are two unique silver metal centres in $\mathbf{3 3}$ but both possess distorted square pyramidal coordination geometry with each $\mathrm{Ag}(\mathrm{I})$ having five contacts within its coordination sphere; four $\mathrm{Ag}-\mathrm{O}$ bonds to four separate coumarin ligands and the fifth contact being to the second Ag atom with the Ag1-Ag2 separation at 2.749 (15) Å) (see Fig. 1). This distance is slightly shorter than that in metallic silver $(2.88 \AA$ ) and significantly less than the van der Waals radii for silver (3.44 $\AA$ ), indicating the presence of metal-metal interaction [23]. The $\mathrm{Ag}-\mathrm{Ag}$ bond is doubly bridged by two carboxylate groups (014, 015, 028 and 029) with $\mathrm{Ag}(\mathrm{I})$ to syn-syn carboxylate oxygen atoms, distances ranging from 2.126(9) (Ag1-O28) to 2.206(9) $\AA$ (Ag2-029). The Ag-carboxylate bonds extend to form a column parallel to the $a$ axis via longer $\mathrm{Ag}-\mathrm{O}$ contacts where $\mathrm{O} 29$ and 014 make a second longer contact with the other crystallographically unique Ag atom [Ag2-O14 2.353(8); 029Ag1 2.384(9) $\AA$ ]. The longest and fifth contact to each Ag atom is to the oxygen of the carboxylic group [Ag1-016 2.497(11) and Ag2-02 $2.500(10) \AA$ ].

The Ag-carboxylate columns lie in an undulating layer sandwiched between layers of coumarin ligands. The intra-layer aromatic rings of the coumarin moieties has a centre-to-centre distance of 3.786(2) $\AA$ which is slightly too long for significant $\pi-\pi$ interactions. The layer formed by each coumarin ligand is extended via $\mathrm{C}-\mathrm{H} \cdots \mathrm{O}$ hydrogen bonds to another coumarin ligand related by a centre of inversion. This makes a stack of coumarin-AgO-coumarin sandwiches parallel to the $c$ axis as shown by the crystal packing in Fig. 2. This type of polymeric structure, where one silver ion has contacts with four different coumarin ligands, has been previously proposed by our group for coumarin carboxylate-based silver(I) complexes [21]. Water molecules build a double column between coumarin ligands forming $\mathrm{O}-\mathrm{H} \cdots \mathrm{O}$ and $\mathrm{C}-\mathrm{H} \cdots \mathrm{O}$ hydrogen bonds with themselves and the coumarin ligands. Crystallographic data for $\mathbf{3 3}$ have been deposited at the Cambridge Crystallographic Data Centre, deposition number CCDC 1437900.

\subsubsection{Experimental and theoretical infrared spectra}

For reliable assignment of the observed IR spectrum of the bridged binuclear $\mathrm{Ag}(\mathrm{I})$ complex (33), molecular structure modeling of

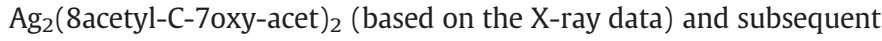
vibrational frequencies calculations were performed, Table 3, Fig. 3.

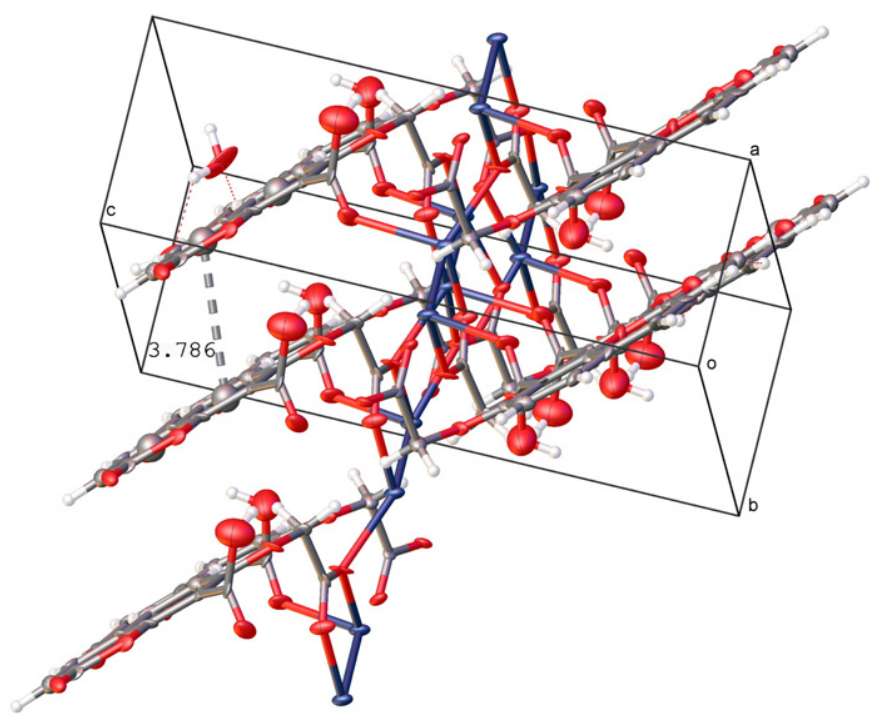

Fig. 2. Crystal packing diagram for $[\mathrm{Ag}(8$ acetyl-C-7oxy-acet) $]$ (33) showing the closest $\pi-\pi$ interaction.

For the $\mathrm{Ag}(\mathrm{I})$ complexes and their phen adducts with unknown crystal and molecular structure, the metal-ligand binding modes and some geometric structure features were predicted on the basis of interpretation of their experimental and calculated IR spectra. The experimental and calculated vibrational spectra of selected ligands (12 and 22 ) and their $\mathrm{Ag}(\mathrm{I})$ complexes $(\mathbf{2 3}, \mathbf{3 4}$, and $\mathbf{4 4}$ ) are shown in Figs. S2-S6 (in Supplementary material).

The vibrational analysis of 12, 13 and $\mathbf{2 2}$ ligands (representatives of the 2-(2-oxo-2H-chromen-substituted-yl)oxy acetic acid group) showed that the first intense band in the $1770-1670 \mathrm{~cm}^{-1}$ region is due to the acidic carbonyl stretching vibration, $\nu(\mathrm{C}=0)_{\mathrm{CoOH}}$ and the second more intense band is due to the coumarin carbonyl one $\left(\nu(C=0)_{\text {coum }}\right)$. In some ligands $(13,14,17)$ only one intense band was observed since the two bands mentioned above were overlapped. The third intense band at $1673 \mathrm{~cm}^{-1}$ in the IR spectrum of 8acetyl-C7oxy-acet ligand (22) was attributed to the $\nu(\mathrm{C}=0)$ vibration of the acetyl group, Fig. S2.

Upon complexation there were significant changes in the region associated with stretching vibrations of the carbonyls most likely as a result of the disappearance of the carboxylic acid functional group from the region whereas the coumarin carbonyl group appeared slightly

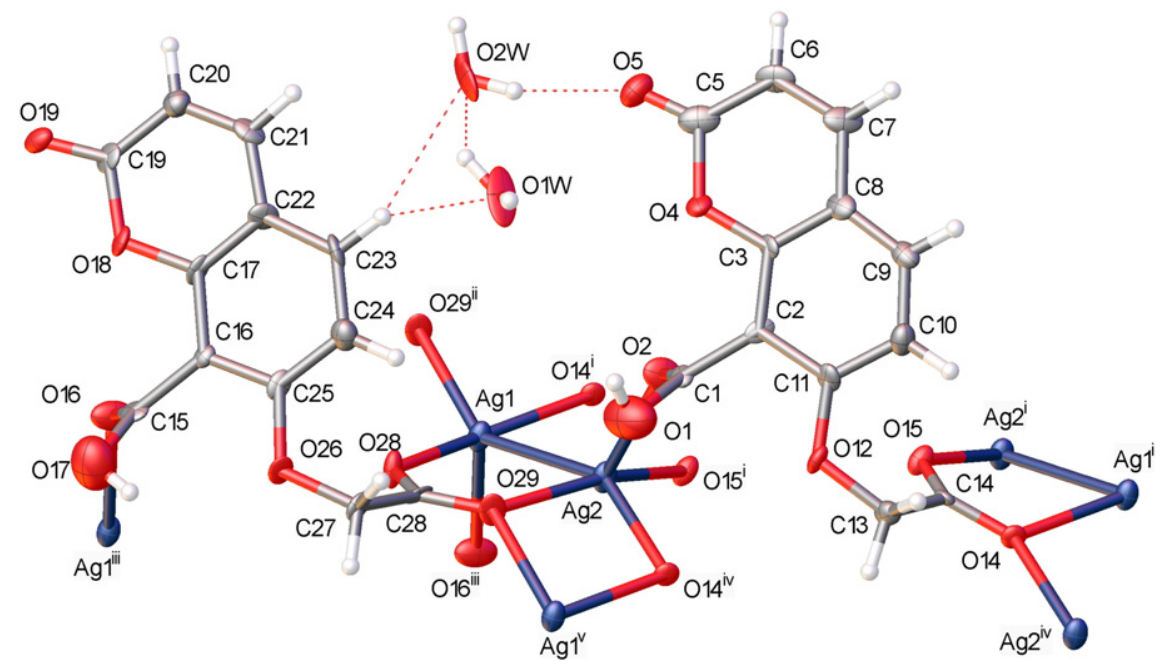

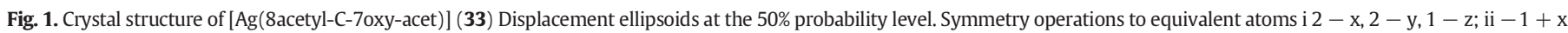
$+\mathrm{y},+\mathrm{z}$; iii $1-\mathrm{x}, 1-\mathrm{y}, 1-\mathrm{z}$; iv $3-\mathrm{x}, 2-\mathrm{y}, 1-\mathrm{z}$; $\mathrm{v} 1+\mathrm{x},+\mathrm{y},+\mathrm{z}$. 


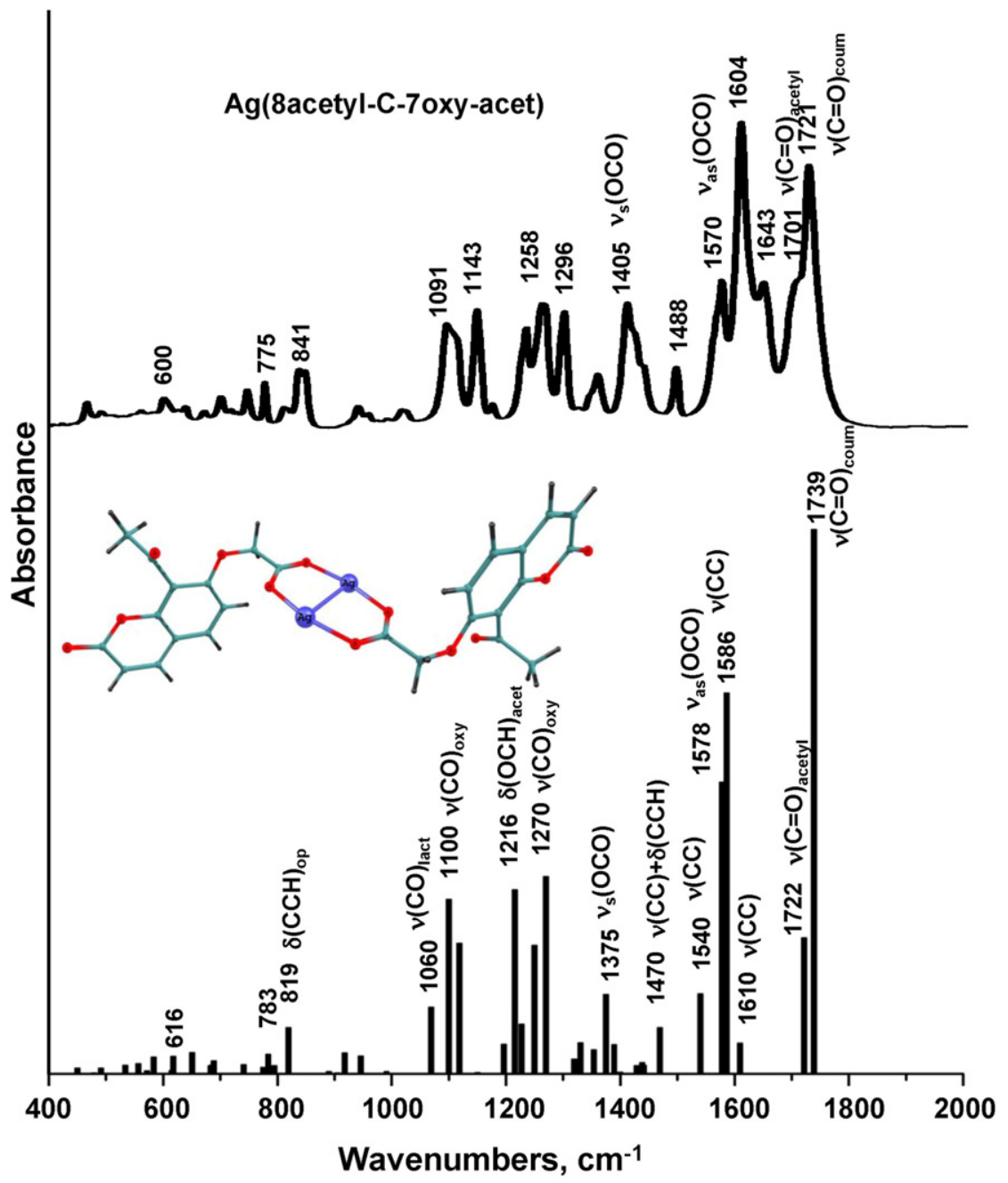

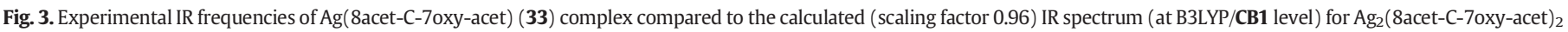
model (taken from X-ray data for 33).

affected (up to $40 \mathrm{~cm}^{-1}$ ). The $v_{\text {asym }}(\mathrm{OCO})$ and $v_{\text {sym }}(\mathrm{OCO})$ vibrational frequencies, together with the $\Delta v(\mathrm{OCO})$ values for the carboxylate group of the selected silver(I) complexes are listed in Table 3. As evidenced by the crystal structure of $\mathbf{3 3}$, the primary ligand bonding type is through carboxylate oxygens to two different $\mathrm{Ag}(\mathrm{I})$ centres, which are involved in oxo-bridge formation, Fig. 1. In addition, the carboxylate oxygens participate in syn-syn bridge formation with other $\mathrm{Ag}(\mathrm{I})$ centre (weaker bonds). The model calculations of $\mathrm{Ag}_{2}$ (8acetyl-C-7oxy-acet) and $\mathrm{Ag}_{2}(\mathrm{C}-3 \text { oxy-acet })_{2}$ species with oxo-bridge simulation reproduce the main vibrational properties, Fig. 3 and Fig. S5, respectively. The calculated $\Delta v\left(\right.$ OCO) values $\left(170-200 \mathrm{~cm}^{-1}\right)$ are in good agreement with the experimental ones. Hence, the $\Delta v$ values for the silver(I) compounds (23-33), which were in the range $150-205 \mathrm{~cm}^{-1}$ appear typical for bidentate bridging bonding [67] as evidenced by the spectra of many such complexes including those of 2-(2-oxo- $2 \mathrm{H}$-chromen-substitutedyl)oxy acetic acid ligands in the $\mathrm{Ag}(\mathrm{I})$ complexes [68].

The microanalytical data for $\mathrm{Ag}(\mathrm{I})$-phen adduct complexes, which suggested an empirical formula of $\mathrm{Ag}(\mathrm{L})$ phen $_{2}$, indicated that the binding mode of the oxyacetate moiety in these adducts would not be the same as in the phen free $\mathrm{Ag}(\mathrm{I})$ complexes. It is likely that in this case the bonding of the carboxylate is via an unidentate carboxylate bond as it was found for the comparable $\mathrm{Ag}(\mathrm{I})$ adduct complexes formed with 4-coumarin carboxylate and phenanthroline [33]. The geometry calculations of possible $\mathrm{Ag}$ (8acetyl-C-7oxy-acet)phen 2 structures confirmed a monomer silver(I) complex with $\mathrm{N}, \mathrm{N}$-bidentate binding of two phen ligands and a monodentate bound coumarin oxyacetate ligand through the carboxylic oxygen, Fig. S3, in Supplementary material. The $\mathrm{V}_{\text {asym }}(\mathrm{OCO})$ and $\mathrm{v}_{\text {sym }}(\mathrm{OCO})$ vibrational frequencies for the silver(I)-phen adduct $\mathbf{4 4}$ were assigned on the basis of IR frequency calculations. The $\Delta v$ value was predicted to be larger as compared to the phen free $\mathrm{Ag}(\mathrm{I})$ complex in agreement with the unidentate carboxylate bond (Table 3 ). The other phen adducts showed similar spectral behaviour. Unfortunately, we were unable to attain a crystal structure for any of the phen adducts. The IR region $1740-1640 \mathrm{~cm}^{-1}$ for the silver(I)-phen adducts $\mathbf{3 4 - 4 4}$ seems similar to the corresponding silver(I) complexes (23-33) in line with the presence of uncoordinated coumarin carbonyl group. The IR spectra of silver(I)phen adducts exhibit additional bands at ca. 1420,840 and $725 \mathrm{~cm}^{-1}$ indicating the presence of 1,10-phenanthroline.

Normally, $\nu(\mathrm{Ag}-\mathrm{O})$ stretching vibrations appear in the 280$250 \mathrm{~cm}^{-1}$ frequency region whereas the $\nu(\mathrm{Ag}-\mathrm{N})$ stretching modes are observed in the $448-362 \mathrm{~cm}^{-1}$ IR and Raman regions [69]. Our vibrational frequency calculations predicted that for the bidentate bridging complexes the $\nu(\mathrm{Ag}-\mathrm{O})$ frequency should be at $\sim 380 \mathrm{~cm}^{-1}$. For $\mathrm{Ag}(\mathrm{I})$-phen adducts (where $\mathrm{N}, \mathrm{N}$-bidentate binding of phen ligands and monodentate binding of coumarinyloxy acetic acid to $\mathrm{Ag}(\mathrm{I})$ were proposed) the $\nu(\mathrm{Ag}-\mathrm{N})$ frequencies should be at $\sim 400 \mathrm{~cm}^{-1}$ and the $\nu(\mathrm{Ag}-\mathrm{O})$ frequency should appear at $\sim 255 \mathrm{~cm}^{-1}$. However, these bands do not fall into the measured IR region.

\subsubsection{Experimental and theoretical NMR spectra}

The formation of silver(I) complexes and their phen adducts in solution was also predicted and confirmed by NMR spectroscopy. The good 
agreement of the experimental and calculated ${ }^{1} \mathrm{H}$ and ${ }^{13} \mathrm{C}$ NMR data of the $\mathrm{Ag}(\mathrm{I})$ complexes 23, 33, 34 (Tables 4 and 5, respectively [70]) confirms the bridging bidentate carboxylate binding in $\mathrm{Ag}(\mathrm{I})$ complexes 23 and $\mathbf{3 3}$ (as it is seen from X-ray analysis of 33) and the monodentate coumarin carboxylate binding in Ag-phen adduct 34. The atom numbering schemes which were used for assignment of ${ }^{1} \mathrm{H}$ and ${ }^{13} \mathrm{C}$ NMR data of the compounds prepared in this study are given in Table 1 . In the ${ }^{1} \mathrm{H}$ NMR spectra of the silver(I) complexes and their phen adducts, the signal that corresponded to the carboxylic acid hydrogen at 13 ppm (for the coumarin ligand) was absent suggesting that the metal binding is via the deprotonated carboxylate group. For the complexes prepared, the ${ }^{1} \mathrm{H}$ NMR signals showed upfield chemical shifts for most of the protons relative to those of the neutral coumarin ligands. The largest upfield shift $(0.3 \mathrm{ppm})$ was observed for the methylene protons $\mathrm{H}^{11}$, which are the closest to the metal binding site, i.e., carboxylate group. The observed slight upfield shifts $(0.1 \mathrm{ppm})$ of the aromatic ${ }^{1} \mathrm{H}$ NMR signals are due to a weakening of the $\pi$-electron delocalization in the ring as a result of electron density withdrawal to $\mathrm{Ag}(\mathrm{I})$, Table 4 . The degree of upfield shifts for $\mathrm{H}^{11}$ and the aromatic hydrogens was greater for the phen adducts compared to the silver(I) complexes (23-33). The ${ }^{1} \mathrm{H}$ NMR spectra of the phen adduct $\mathbf{3 4}$ have additional signals at ca. 9.15 $\left(\mathrm{H}^{\mathrm{a}}\right), 7.95\left(\mathrm{H}^{\mathrm{b}}\right), 8.70\left(\mathrm{H}^{\mathrm{c}}\right), 8.15 \mathrm{ppm}\left(\mathrm{H}^{\mathrm{d}}\right)$, which correspond to the phen ligands and the relative integration confirmed a 1:2 coumarin:phen ratio. All of these signals had shifted downfield relative to the corresponding signals in the free phen $(9.11,7.79,8.50,8.00 \mathrm{ppm})$ [71].

Typically, ${ }^{13} \mathrm{C}$ NMR spectra of 2-(2-oxo-2H-chromen-substitutedyl)oxy acetic acid-based silver(I) complexes and their phen adducts exhibited downfield chemical shifts relative to the corresponding ligands (Table 5). The most significant downfield shift observed was for $\mathrm{C}^{11}$ being $\alpha$ to the carboxylate group and near to the complexation site. The degree of downfield shifts for $\mathrm{C}^{11}$ was greater for the phen adducts compared to the silver(I) complexes (23-33). ${ }^{13} \mathrm{C}$ NMR chemical shifts for $\mathrm{C}^{12}$ of the carboxylate group, being the coordination site, was also shifted after complexation as it is observed in the case of substituted coumarin-3carboxylatosilver(I) complexes [21]. It should be noted that in case of the $\mathrm{Ag}(\mathrm{I})$ complexes (23-33) the $\mathrm{C}^{12}$ signal is slightly shifted downfield, whereas in their phen adducts the $\mathrm{C}^{12}$ signal is shifted upfield (by $\sim 1 \mathrm{ppm}$ ) as compared to the free ligand. This result could be related to the different bonding of carboxylate group - bidentate bridging and monodentate, respectively. Vinylic carbon and aromatic carbons show a small degree of shielding effect upon complexation. In the ${ }^{13} \mathrm{C}$ NMR spectra of silver(I)-phen adduct 34 the phenanthroline peaks at ca. $151.0\left(\mathrm{C}^{18}\right)$, $142.0\left(C^{23}\right), 138.0\left(C^{20}\right), 129.0\left(C^{21}\right), 127.0\left(C^{22}\right)$ and $125.0\left(C^{19}\right) \mathrm{ppm}$ were observed indicating the presence of phenanthroline ligands. Due to the $\mathrm{N}, \mathrm{N}$-coordination of phen to $\mathrm{Ag}(\mathrm{I})$ the $\mathrm{C}^{18}, \mathrm{C}^{20}, \mathrm{C}^{19}$ signals were downfield shifted relative to free phen $(149.9,136.1,123.2 \mathrm{ppm})$, whereas the $C^{23}$ is upfield shifted ( 145.5 ppm for phen). The $C^{21}$ and $C^{22}$ signals were not changed in the $\mathrm{Ag}(\mathrm{I})$ complexes. The similarity of the coumarin and phen signals in the ${ }^{1} \mathrm{H}$ and ${ }^{13} \mathrm{C}$ NMR spectra in solution for the $\mathrm{Ag}(\mathrm{I})$ complexes (23-33) on the one hand and for Ag-phen adducts (34-44) on the other hand, indicated that the ligands would appear in an identical coordination behaviour: bridging bidentate carboxylate binding and monodentate carboxylate binding of coumarins, respectively and for the phen adducts the two phen ligands are coordinated to the silver ion through the two nitrogen donors (Tables 4 and 5).

\subsubsection{Experimental and theoretical UV-Vis spectroscopic analysis}

The UV-Vis spectra of the silver(I) complexes and their phen adducts were compared to the electronic spectra of the corresponding ligands. The electronic spectral data, i.e., the maximum absorption wavelength $\left(\lambda_{\max }\right.$ in $\mathrm{nm}$ ) and the molar absorptivity (extinction coefficients, $\mathrm{M}^{-1} \mathrm{~cm}^{-1}$ ) for all of the complexes and phen adducts along with the corresponding ligands are given in Table 6 . The UV-Vis spectra of selected $\mathrm{Ag}(\mathrm{I})$ complexes are shown in the Fig. S7 (in Supplementary material) and are typical for the spectra obtained for the other coordination compounds in this series. The observed UV-Vis spectra of C-3oxyacetH (12) and 8acetyl-C-7oxy-acet (22) ligands and their $\mathrm{Ag}(\mathrm{I})$ complexes 23 , and $\mathbf{3 3}$, and the phen adduct 34 were analysed on the basis of TDDFT/B3LYP/CB1 calculations of the vertical excitation energies in solution (DMSO) for the model compounds, Table 6. The TDDFT calculations of the model ligands $\mathbf{1 2}$ and $\mathbf{2 2}$ well reproduce the absorption bands at $310 \mathrm{~nm}$ and $280 \mathrm{~nm}$ for 12 and at 320, 290 and $240 \mathrm{~nm}$ for 22 ligand and they are assigned to ${ }^{1} \mathrm{~A}\left(\pi \pi^{*}\right)$ excited states (the first band corresponds to the $2^{1} \mathrm{~A}\left(\pi \pi^{*}\right)$ excited state).

The observed absorption bands at 310, 290 and $240 \mathrm{~nm}$ for $\mathrm{Ag}(\mathrm{I})$ complex 23 are due to the ligand $\mathrm{L}(\pi)-\mathrm{L}\left(\pi^{*}\right)$ electron transitions and they are almost unchanged as compared to the ligand (12) absorption bands. The corresponding $\mathrm{Ag}(\mathrm{I})$-phen adduct $\mathbf{3 4}$, however, shows a new absorption band at $325 \mathrm{~nm}$ assigned to the electron transition from a mixed orbital, involving $\mathrm{Ag}\left(\mathrm{sd}_{\mathrm{xy}}\right), \mathrm{C}-30 x y$-acet and phen contributions to phen $\left(\pi^{*}\right)$ orbital.

The typical UV-Vis bands of 8acetyl-C-7oxy-acet appear in the spectrum of its $\mathrm{Ag}(\mathrm{I})$ complex 33 and they are assigned to $\mathrm{L}(\pi)-\mathrm{L}\left(\pi^{*}\right)$ transitions. The intensity of the band at $285 \mathrm{~nm}$ is strongly increased in the $\mathrm{Ag}$ complex. A new band at $265 \mathrm{~nm}$ appears for the $\mathrm{Ag}(\mathrm{I})$ complex $\mathbf{3 3}$, which is attributed to the transition from $\mathrm{L}(\pi)$ orbital to the mixed orbital, with $\mathrm{Ag}(\mathrm{sd}), \mathrm{O}_{\text {carbox }}$ and $\mathrm{O}_{\text {acet }}$ contributions. The good agreement of the experimental and calculated excitation energies confirmed the suspected structures of the ligands and their $\mathrm{Ag}(\mathrm{I})$ complexes in solution.

In summary, the electronic spectral data of the complexes and phen adducts exhibited one, two or three bands in the UV region. Typically, the electronic spectra of silver(I) complexes $\mathbf{2 3 , 2 6 - 3 2}$ and phen adducts 37-44 exhibited red shifts for at least one of the absorption bands (345 to $280 \mathrm{~nm}$ ) while [Ag(C-3oxy-acet)phen ${ }_{2}$ ( 34 ) showed a blue shift to $305 \mathrm{~nm}$. However, in some cases no change in energy was observed compared to the corresponding 2-(2-oxo- $2 \mathrm{H}$-chromen-substitutedyl)oxy acetic acid ligands e.g., $[\mathrm{Ag}(\mathrm{C}-40 x y-a c e t)](\mathbf{2 4})$ and $[\mathrm{Ag}(6 \mathrm{Cl}-\mathrm{C}$ 4oxy-acet)] (25). The theoretical analysis of selected $\mathrm{Ag}(\mathrm{I})$ complexes 23, 34 and 33 (along with the ligands 12 and 22) revealed also an appearance of new absorption bands in their UV-Vis spectra. For phen adducts 34-44, an increase in the molar absorptivity values was observed. This could be due to the presence of multiple organic species (ligand and phen). All of the silver(I) complexes 23-33 showed a decrease in the molar absorptivity values compared to the corresponding 2-(2oxo- $2 \mathrm{H}$-chromen-substituted-yl)oxy acetic acid ligands. The observed shifts in wavelength $\left(\lambda_{\max }\right)$ and molar absorptivity value may be attributed to the possibility of polarization of the ligand caused by the metalligand electron interaction [72].

\subsection{Determination of antibacterial activities}

The $\mathrm{MIC}_{50}$ values, (the concentration of test compound that inhibits growth by $50 \%$ relative to an untreated control) were determined using methicillin resistant Staphylococcus aureus, MRSA strain, ATCC 4300, (Manassas, VA, USA) and P. aeruginosa strain, ATCC 27853, as test organisms. Initially, each compound was screened using a single independent broth microdilution experiment in order to shortlist the most active compounds. Once the most active compounds were identified, they were tested in triplicate along with a commercially available antibacterial drug, Vancomycin, according to the broth microdilution method [60].

The results of this set of screening experiments are given in Table 7 as $\mathrm{MIC}_{50}$ values in $\mu \mathrm{M}$. Complexes $\mathbf{3 5 , ~ 3 6 , 4 1}$ and $\mathbf{4 2}$ were tested as suspensions since they were not soluble at the final concentration of DMSO. All of the ligands 12-22 were found to be inactive even at the highest concentration of $100 \mu \mathrm{M}$ against both bacterial strains. The $\mathrm{MIC}_{50}$ values of complexes 23-33 against $P$. aeruginosa ranged from ca. 19 to $36 \mu \mathrm{M}$, indicating the bactericidal potential of these complexes against a resistant Gram-negative strain. Moreover, they were found to be more active than silver(I) nitrate and Vancomycin (Table 7). On the other hand, the 
$\mathrm{MIC}_{50}$ values of these complexes against MRSA were comparable to the $\mathrm{MIC}_{50}$ value of silver(I) nitrate but were much higher than that of Vancomycin, $(1.0 \pm 0.1 \mu \mathrm{M})$. Silver(I) nitrate has a much higher solubility in aqueous systems than the complexes tested here. The 1,10phenanthroline adducts 34-44 of these complexes also followed the same trend with the complexes showing higher activity against the Gram-negative strain and indeed incorporation of 1,10-phenanthroline molecules into the molecular framework resulted in significantly increased activity as observed from related previous studies [39,73-75].

The silver(I) complexes and their 1,10-phenanthroline adducts differ in the substituents present on the coumarin nucleus but it was not possible to correlate the observed activity with any physicochemical characteristic since within experimental errors, the obtained $\mathrm{MIC}_{50}$ values were found to be comparable with the exception of $\mathrm{Ag}$ (8acetylC-7oxy-acet) (33). This increase in the effectiveness of $\mathbf{3 3}$ could be attributed to its increased solubility and related bioactivity, induced by the presence of an acetyl group. Overall, the silver(I) complexes showed selectivity towards Gram-negative bacteria relative to Gram-positive bacteria.

\subsection{Determination of antifungal activities}

In this study, the ligands, their metal complexes and 1,10phenanthroline adducts were tested for their anti-Candida activity using a broth microdilution susceptibility protocol established by the National Committee for Clinical Laboratory Standards (NCCLS), document M27-A2 with slight modifications. The M27-A2 method was altered by substituting antibiotic medium 3 (Oxoid Ltd.) for RPMI 1640 medium [60].

All of the test compounds were prepared in $2 \%$ DMSO solution as this solvent system is frequently used for antifungal testing of drugs and the results given in Table 8. Once again, complexes 35, 36, 41 and 42 were tested as suspensions since they were not soluble at the final concentration of DMSO. The maximum concentration of the DMSO, after serial

Table 7

Activity of ligands (12-22), silver(I) complexes (23-33) and phen adducts (34-44) against MRSA and $P$. aeruginosa expressed as $\mathrm{MIC}_{50}$ values.

\begin{tabular}{|c|c|c|}
\hline Compound & $\begin{array}{c}\text { MRSA } \\
\text { MIC }_{50} \text { values } \\
{[(\mu \mathrm{M} \pm \mathrm{SEM})]}\end{array}$ & $\begin{array}{l}\text { P. aeruginosa } \\
\mathrm{MIC}_{50} \text { values } \\
{[(\mu \mathrm{M} \pm \mathrm{SEM})]}\end{array}$ \\
\hline Ligands (12-22) & Inactive & Inactive \\
\hline$[\mathrm{Ag}(\mathrm{C}-3$ oxy-acet $)](\mathbf{2 3})$ & $47 \pm 12$ & $36.0 \pm 0.4$ \\
\hline$[\mathrm{Ag}(\mathrm{C}-4 \mathrm{oxy}$-acet $)] \cdot 1.4 \mathrm{H}_{2} \mathrm{O}(\mathbf{2 4})$ & $41 \pm 8$ & $34.7 \pm 1.3$ \\
\hline$[\mathrm{Ag}(6 \mathrm{Cl}-\mathrm{C}-4 \mathrm{oxy}$-acet $)](\mathbf{2 5})$ & $47 \pm 12$ & $23.6 \pm 0.4$ \\
\hline$[\mathrm{Ag}(\mathrm{C}-6$ oxy-acet $)] \cdot 0.4 \mathrm{H}_{2} \mathrm{O}(\mathbf{2 6})$ & $49 \pm 13$ & $35.7 \pm 0.6$ \\
\hline$[\mathrm{Ag}(4 \mathrm{Me}-\mathrm{C}-60 x y-$ acet $)] \cdot 2.2 \mathrm{H}_{2} \mathrm{O}(\mathbf{2 7})$ & $47 \pm 16$ & $18.9 \pm 0.4$ \\
\hline$[\mathrm{Ag}(\mathrm{C}-7$ oxy-acet $)](\mathbf{2 8})$ & $48 \pm 17$ & $19.6 \pm 0.6$ \\
\hline [Ag(4Me-C-7oxy-acet)] (29) & $48 \pm 15$ & $32.8 \pm 1.7$ \\
\hline$[\mathrm{Ag}(3,4,8$-triMe-C-7oxy-acet) $]$ (30) & $41 \pm 9$ & $23.9 \pm 0.4$ \\
\hline$[\mathrm{Ag}(3 \mathrm{Cl}-4 \mathrm{Me}-\mathrm{C}-7 \mathrm{oxy}$-acet $)] \cdot 0.8 \mathrm{H}_{2} \mathrm{O}(\mathbf{3 1})$ & $47 \pm 15$ & $23.7 \pm 0.1$ \\
\hline [Ag(4CF3-C-7oxy-acet)].1.5 $\mathrm{H}_{2} \mathrm{O}(32)$ & $50 \pm 12$ & $31.4 \pm 0.7$ \\
\hline$[\mathrm{Ag}$ (8acetyl-C-7oxy-acet) $](\mathbf{3 3})$ & $33 \pm 1$ & $22.7 \pm 0.3$ \\
\hline$\left[\mathrm{Ag}(\mathrm{C}-3\right.$ oxy-acet $)$ phen $\left._{2}\right](\mathbf{3 4})$ & $17 \pm 1$ & $17.6 \pm 0.2$ \\
\hline$\left[\mathrm{Ag}(\mathrm{C}-4\right.$ oxy-acet $)$ phen $\left._{2}\right](\mathbf{3 5})$ & $29 \pm 3$ (susp) & $17.1 \pm 0.2$ (susp) \\
\hline$\left[\mathrm{Ag}(6 \mathrm{Cl}-\mathrm{C}-4 \mathrm{oxy}\right.$-acet $\left.) \mathrm{phen}_{2}\right](\mathbf{3 6})$ & $25 \pm 1$ (susp) & $18.0 \pm 0.1$ (susp) \\
\hline$\left[\mathrm{Ag}(\mathrm{C}-60 x y-a c e t)\right.$ phen $\left._{2}\right](37)$ & $38 \pm 1$ & $17.4 \pm 0.1$ \\
\hline [Ag(4Me-C-6oxy-acet)phen 2$](38)$ & $18 \pm 0.05$ & $17.0 \pm 0.0$ \\
\hline$\left[\mathrm{Ag}(\mathrm{C}-7\right.$ oxy-acet $)$ phen $\left._{2}\right](\mathbf{3 9})$ & $29 \pm 2$ & $17.4 \pm 0.1$ \\
\hline$\left[\mathrm{Ag}(4 \mathrm{Me}-\mathrm{C}-7\right.$ oxy-acet $)$ phen $\left._{2}\right](\mathbf{4 0})$ & $30 \pm 0.5$ & $17.2 \pm 0.1$ \\
\hline$\left[\mathrm{Ag}\left(3,4,8\right.\right.$-triMe-C-7oxy-acet) phen $\left._{2}\right](\mathbf{4 1})$ & $25 \pm 3$ (susp) & $17.5 \pm 0.3$ (susp) \\
\hline$\left[\mathrm{Ag}(3 \mathrm{Cl}-4 \mathrm{Me}-\mathrm{C}-7\right.$ oxy-acet $)$ phen $\left._{2}\right](\mathbf{4 2})$ & $28 \pm 6$ (susp) & $16.7 \pm 0.2($ susp $)$ \\
\hline [Ag(4CF3-C-7oxy-acet)phen 2$](43)$ & $16 \pm 1$ & $16.9 \pm 0.1$ \\
\hline$[\mathrm{Ag}$ (8acetyl-C-7oxy-acet)phen 2$](\mathbf{4 4})$ & $21 \pm 1$ & $17.4 \pm 0.1$ \\
\hline Silver(I) nitrate $\left(\mathrm{AgNO}_{3}\right)$ & $54 \pm 2$ & $51.4 \pm 14.1$ \\
\hline Dimethyl sulfoxide (DMSO) & Inactive & Inactive \\
\hline 1,10-Phenanthroline & $51 \pm 2$ & Inactive \\
\hline Vancomycin & $1.0 \pm 0.1$ & $66.3 \pm 2.5$ \\
\hline
\end{tabular}

Table 8

Activity of ligands (12-22), silver(I) complexes (23-33) and phen adducts (34-44)against $C$. albicans expressed as $\mathrm{MIC}_{50}$ values.

\begin{tabular}{|c|c|}
\hline Compound & $\mathrm{MIC}_{50}$ values $[(\mu \mathrm{M} \pm \mathrm{SEM})]$ \\
\hline Ligands (12-22) & Inactive \\
\hline Silver(I) complexes 24-26, 29, 30, 32, 33 & Inactive \\
\hline$[\mathrm{Ag}(\mathrm{C}-3$ oxy-acet $)](\mathbf{2 3})$ & $91.7 \pm 16.5$ \\
\hline$[\mathrm{Ag}(4 \mathrm{Me}-\mathrm{C}-60 x y-a c e t)] \cdot 2 \cdot 2 \mathrm{H}_{2} \mathrm{O}(\mathbf{2 7})$ & $81.5 \pm 17.0$ \\
\hline$[\mathrm{Ag}(\mathrm{C}-7$ oxy-acet $)](\mathbf{2 8})$ & $79.4 \pm 2.2$ \\
\hline$[\mathrm{Ag}(3 \mathrm{Cl}-4 \mathrm{Me}-\mathrm{C}-7 \mathrm{oxy}-\mathrm{acet})] \cdot 0.8 \mathrm{H}_{2} \mathrm{O}$ (31) & $96.7 \pm 4.6$ \\
\hline$\left[\mathrm{Ag}(\mathrm{C}-3\right.$ oxy-acet $)$ phen $\left._{2}\right](\mathbf{3 4})$ & $7.7 \pm 0.2$ \\
\hline$\left[\mathrm{Ag}(\mathrm{C}-4\right.$ oxy-acet $)$ phen $\left._{2}\right](\mathbf{3 5})$ & $11.7 \pm 0.3$ (susp) \\
\hline [Ag(6Cl-C-4oxy-acet)phen 2$]$ (36) & $32.1 \pm 0.9$ (susp) \\
\hline$\left[\mathrm{Ag}(\mathrm{C}-60 x y\right.$-acet $\left.) \mathrm{phen}_{2}\right](37)$ & $25.1 \pm 0.7$ \\
\hline [Ag(4Me-C-6oxy-acet)phen 2$]$ (38) & $7.5 \pm 0.2$ \\
\hline$\left[\mathrm{Ag}(\mathrm{C}-7\right.$ oxy-acet $)$ phen $\left._{2}\right](\mathbf{3 9})$ & $22.6 \pm 0.8$ \\
\hline [Ag(4Me-C-7oxy-acet)phen 2$](40)$ & $13.2 \pm 2.2$ \\
\hline$[\mathrm{Ag}(3,4,8$-triMe-C-7oxy-acet)phen 2$](\mathbf{4 1})$ & $58.3 \pm 2.4$ (susp) \\
\hline$\left[\mathrm{Ag}(3 \mathrm{Cl}-4 \mathrm{Me}-\mathrm{C}-7\right.$ oxy-acet $)$ phen $\left._{2}\right](\mathbf{4 2})$ & $35.1 \pm 1.0$ (susp) \\
\hline [Ag(4CF3-C-7oxy-acet)phen 2$](43)$ & $10.3 \pm 0.2$ \\
\hline [Ag(8acetyl-C-7oxy-acet)phen 2$](44)$ & $9.2 \pm 0.5$ \\
\hline Silver(I) nitrate $\left(\mathrm{AgNO}_{3}\right)$ & $38.4 \pm 2.6$ \\
\hline Dimethyl sulfoxide (DMSO) & Inactive \\
\hline 1,10-Phenanthroline & $22.5 \pm 3.7$ \\
\hline Amphotericin B & $4.3 \pm 0.4$ \\
\hline
\end{tabular}

dilution, in the test wells was $0.5 \%$, a concentration which was found to be non-toxic to the tested cells. The ligands, complexes and a commercially available antifungal drug, Amphothericin B were tested against C. albicans strain ATCC 10231. The metal-free ligands were found to be inactive as were silver(I) complexes 24-26, 29, 30, 32 and 33. Low anti-Candida activity ( 79 to $97 \mu \mathrm{M}$ ) was exhibited by silver(I) complexes 23, 27, 28 and $\mathbf{3 1}$.

On the other hand, the adducts formed by these silver(I) complexes with 1,10-phenanthroline showed significant anti-Candida activity with most showing better activity than the silver(I) nitrate salt. Complexes 38, 43 and $\mathbf{4 4}$ all showed excellent activity (Table 8 ) comparable to the benchmark $\mathrm{MIC}_{50}$ values of the commercial drugs Amphotericin B i.e., $4.3 \mu \mathrm{M}$ and Ketoconazole i.e. $4.7 \mu \mathrm{M}$ [75]. It is difficult to suggest a definitive structure-activity relationship based upon the differences in physicochemical properties of these complexes given their comparable antimicrobial activities. The improvement in anti-Candida activity was expected from the 1,10-phenanthroline adducts of silver(I) complexes because such improvement in activity is well documented $[39,73,74]$. Moreover, this activity could also be attributed to the presence of three structural moieties, the coumarin-derived ligand and two 1,10phenanthroline ligands in one molecular frame, which become biologically active upon coordinating to a metal centre.

Table 9

$\mathrm{IC}_{50}$ values (in $\mu \mathrm{M}$ ) for tested complexes against human-derived cancer cell lines.

\begin{tabular}{|c|c|c|}
\hline Compound & $\begin{array}{l}\mathrm{A} 498 \\
(\mu \mathrm{M} \pm \mathrm{SEM})\end{array}$ & $\begin{array}{l}\text { HepG2 } \\
(\mu \mathrm{M} \pm \mathrm{SEM})\end{array}$ \\
\hline All ligands & Inactive & Inactive \\
\hline$[\mathrm{Ag}(\mathrm{C}-30 x y-a c e t)](\mathbf{2 3})$ & $64.70 \pm 5.10$ & $40.50 \pm 4.10$ \\
\hline$[\mathrm{Ag}(\mathrm{C}-40 x y$-acet $)] \cdot 1.4 \mathrm{H}_{2} \mathrm{O}(\mathbf{2 4})$ & $64.20 \pm 3.70$ & $47.20 \pm 3.90$ \\
\hline$[\mathrm{Ag}(6 \mathrm{Cl}-\mathrm{C}-4 \mathrm{oxy}-\mathrm{acet})](\mathbf{2 5})$ & $71.50 \pm 11.20$ & $34.30 \pm 1.70$ \\
\hline$[\mathrm{Ag}(\mathrm{C}-6$ oxy-acet $)] \cdot 0.4 \mathrm{H}_{2} \mathrm{O}(\mathbf{2 6})$ & $56.40 \pm 1.40$ & $40.10 \pm 2.20$ \\
\hline$[\mathrm{Ag}(4 \mathrm{Me}-\mathrm{C}-60 x y-a c e t)] \cdot 2.2 \mathrm{H}_{2} \mathrm{O}(27)$ & $60.50 \pm 2.90$ & $28.10 \pm 4.30$ \\
\hline$[\mathrm{Ag}(\mathrm{C}-7$ oxy-acet $)](\mathbf{2 8})$ & $55.60 \pm 2.70$ & $44.00 \pm 2.80$ \\
\hline [Ag(4Me-C-7oxy-acet)] (29) & Inactive & $36.30 \pm 3.20$ \\
\hline [Ag(3,4,8-triMe-C-7oxy-acet)] (30) & $61.00 \pm 6.80$ & $24.90 \pm 4.70$ \\
\hline$[\mathrm{Ag}(3 \mathrm{Cl}-4 \mathrm{Me}-\mathrm{C}-7 \mathrm{oxy}-\mathrm{acet})] \cdot 0.8 \mathrm{H}_{2} \mathrm{O}(\mathbf{3 1})$ & $51.40 \pm 1.30$ & $29.40 \pm 1.80$ \\
\hline$[\mathrm{Ag}(4 \mathrm{CF} 3-\mathrm{C}-7$ oxy-acet $)] \cdot 1.5 \mathrm{H}_{2} \mathrm{O}(32)$ & $58.30 \pm 0.5$ & $26.30 \pm 5.0$ \\
\hline [Ag(8acetyl-C-7oxy-acet)] (33) & $63.30 \pm 5.50$ & $27.40 \pm 1.70$ \\
\hline Silver(I) nitrate $\left(\mathrm{AgNO}_{3}\right)$ & $49.80 \pm 3.00$ & $32.30 \pm 4.00$ \\
\hline 1,10-Phenanthroline & $>100$ & $>100$ \\
\hline Mitoxantrone & $72.70 \pm 10.80$ & $38.90 \pm 0.40$ \\
\hline
\end{tabular}




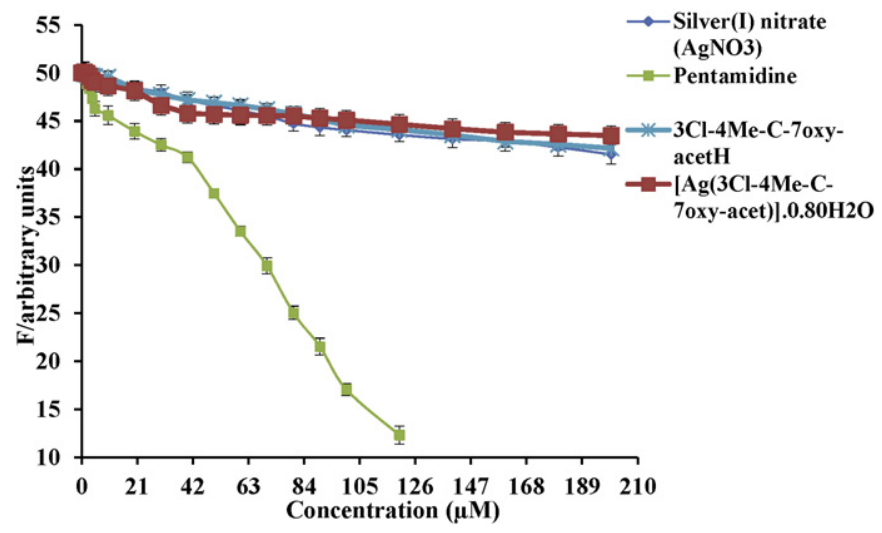

Fig. 4. Competitive ethidium bromide displacement for pentamidine, $3 \mathrm{Cl}-4 \mathrm{Me}-\mathrm{C}-7 \mathrm{oxy}-$ acetH (21), silver nitrate and $[\mathrm{Ag}(3 \mathrm{Cl}-4 \mathrm{Me}-\mathrm{C}-7 \mathrm{oxy}-\mathrm{acet})] 0.8 \mathrm{H}_{2} \mathrm{O}$ (31) with CT-DNA shown up to $200 \mu \mathrm{M}$.

\subsection{Determination of cytotoxicity}

The improved solubility of complex 33, relative to the other silver(I) complexes, did not result in any increased activity against microbial cells. A number of previous studies on related complexes had shown that silver(I) complexes of coumarins were active against immortalised cell lines [76] and it was thought that the increased solubility of compound $\mathbf{3 3}$ may give rise to an increase in cytotoxicity against mammalian-derived cells. Thus that series of derivatives were screened for their cytotoxicity against two cell lines, HepG2 cell line, which is a liver-derived cell line, and A498, which is a renal cell line. As can be seen from Table 9 the cytotoxicities of the complexes were similar to that of silver nitrate (and indeed comparable to that of the control mitoxantrone) but the most soluble complex again did not show any significantly different activity in comparison to the other complexes. However the complexes isolated did have significant cytotoxicity as we have recently identified two series of related complexes, one series based on hydroxynitro-coumarin complexes of silver(I) [76] and another series based on silver(I) dicarboxylates [37], both of which had shown cytotoxicity but whose mechanism of action seemed to be related to their ability to act as antioxidants, and we were interested to see if that was the case here.

\subsection{DNA binding properties}

Complex 31 was chosen for these studies as it had reasonable cytotoxicity against both mammalian cell lines and was active against the bacterial and fungal cell lines tested. Many anti-cancer drugs are thought to exert their effect though DNA binding ability and though there are reports of antimicrobial compounds acting by interfering with DNA synthesis in a bacterial cell [77]. A recent report has shown that an azolylthioetherquinolone complex, which had excellent activity against the two bacterial strains used in these studies, exerted its effect via intercalation into MRSA DNA through a copper ion bridge [78]. Another paper recently published on bisimidazolium-tagged acridines showed that these compounds had both anti-bacterial and DNA-binding ability [79].

To confirm whether the silver complex 31, [Ag(3Cl-4Me-C-7oxyacet) $] 0.8 \mathrm{H}_{2} \mathrm{O}$ had DNA binding ability, competitive EtBr displacement experiments were conducted with the complex along with its corresponding ligand, 21, and a known intercalator pentamidine using CTDNA over the concentration range of 1 to $1000 \mu \mathrm{M}$. Ethidium bound DNA is highly fluorogenic and in the presence of excess ethidium ion $\left(\mathrm{Et}^{+}\right)$, binding regions within the DNA polymer become saturated. Thus, during competitive displacement, an exogenous reagent must 'compete' at the binding site with $\mathrm{Et}^{+}$resulting in a sequential reduction in fluorescence.

As can be seen from Fig. 4, neither the complex, ligand or silver nitrate appears to bind to DNA via intercalation as no displacement of $\mathrm{EtBr}$ was seen. Pentamidine was highly efficient in the displacement of $\mathrm{Et}^{+}$bound DNA and, as expected, its apparent binding constant $\left(K_{\mathrm{app}}=1.50 \times 10^{5}\right)$. The coumarin-derived silver complex which exhibited cytotoxicity and antimicrobial activity, did not appear to mediate its effect through DNA interaction/binding (which can happen through a number of modes) and therefore are likely to target other sites in the cell other than DNA.

A number of recent papers highlighted the link between antimicrobial activity and DNA binding and/or nuclease activity suggesting potential mechanisms for antimicrobial activity that involve binding and/or irreversible cleavage of bacterial nucleic acids [80]. The nuclease activities of the complex and its corresponding ligand were analysed by monitoring the unwinding of supercoiled pBR322 plasmid DNA (Form A) to open DNA (Form C) or linear circular (Form B) over a concentration range of $50-0.50 \mu \mathrm{M}$ for $5 \mathrm{~h}$ without an added reductant (Figs. 5 and 6).The extent of strand scission was assessed by agarose gel electrophoresis and compared to copper bisphenanthroline (positive control).

It can be seen from these figures that neither the metal-free ligand or the silver(I) complex exhibited self-cleaving of supercoiled (SC) DNA (Form A). Copper bisphenanthroline partially cleaved SC DNA (Form A) to open circular OC (Form C) at $50 \mu \mathrm{M}$ (lane 7). Moreover, neither complex nor controls cleaved DNA even in the presence of added reductant (mercaptopropanoic acid) at twice the concentration of the test compounds (Fig. 6). However, in this case the highest concentrations $(50 \mu \mathrm{M})$ of copper bisphenanthroline showed a partial nuclease activity.

\subsection{SOD mimetic activity}

Related silver(I) complexes which have shown good antimicrobial activity and cytotoxicity and which did not show DNA intercalation or nuclease activity did show potential to reduce oxidative stress in the yeast $S$. cerevisiae or in cell free models $[37,76]$. The SOD mimetic ability of complex $\mathbf{3 1}$ was tested for its ability to inhibit the reduction of NBT to blue formazan by the scavenging of the superoxide radicals, which were

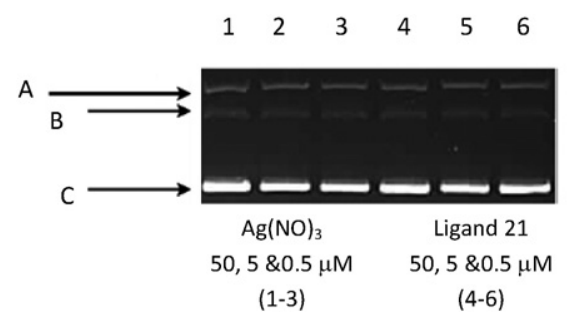

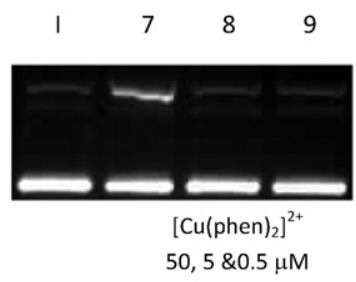

(7-9)

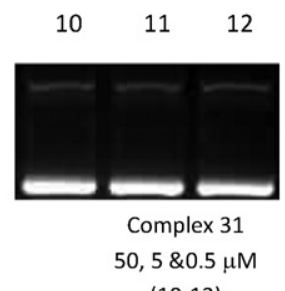

(10-12)

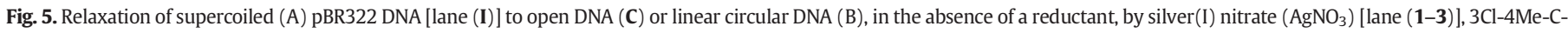

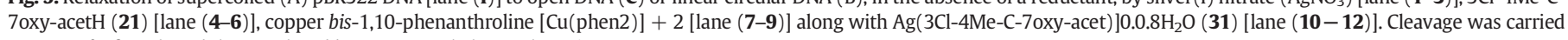
out at $37^{\circ} \mathrm{C}$ for $5 \mathrm{~h}$ and then analysed by agarose gel electrophoresis. 


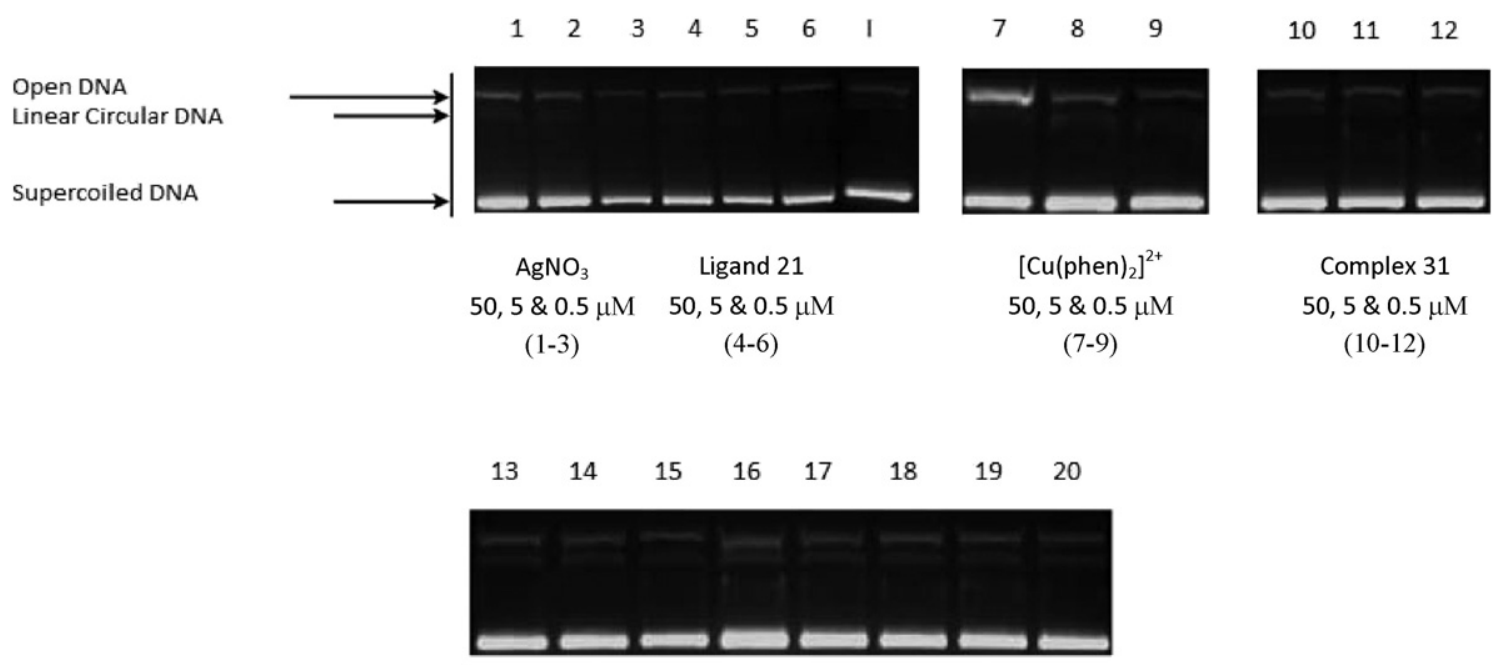

Mercaptopropanoic acid

$250,100,50,25,10,5 \& 1 \mu \mathrm{M}$

(13-20)

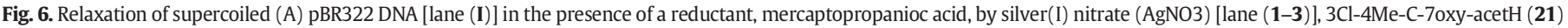

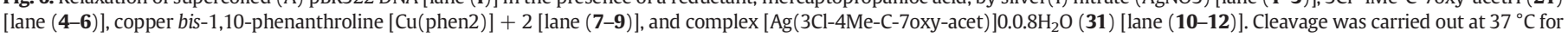
$5 \mathrm{~h}$ and then analysed by agarose gel electrophoresis.

generated by xanthine oxidase during the conversion of xanthine to urate. $\mathrm{EC}_{50}$ values were considered to be the concentration $(\mu \mathrm{M})$ equivalent to 1 unit of a bovine erythrocyte SOD activity and therefore the lower the magnitude of $\mathrm{EC}_{50}$, the higher will be the SOD mimic activity of the complex. The free ligand $\mathbf{2 1}$ did not exhibit SOD activity but complex 31 did show SOD activity $\left(\mathrm{EC}_{50}=1.20 \pm 0.06 \mu \mathrm{M}\right)$, albeit lower than that of native SOD $\left(\mathrm{EC}_{50}=0.04 \mu \mathrm{M}\right)$, and indeed also higher than silver(I) nitrate $0.15 \pm 0.07 \mu \mathrm{M}$. The role of silver(I) complexes in the redox processes in the cell has been identified by a number of workers in terms or disruption of mitochondrial function but in more recent times there have been reports where the SOD activity in cells is increased in the presence of colloidal silver and that group posed the hypothesis that up-regulation of the SOD enzymes was occurring as a result of the presence of the silver [81]. In another study the effect of silver nanoparticle reduced the antioxidative biomarkers in rats which were under oxidative stress [82]. The role of silver(I) complexes is thus under current debate but the activity of the complexes isolated here, which have antimicrobial, antifungal and cytotoxic effects may have a mechanism of action related to their ability to act as antioxidants rather than by intercalation or nuclease activity which has been shown by others in the field as outlined earlier.

\section{Conclusions}

A range of novel silver(I) complexes of coumarin-derived oxyacetate ligands and their 1,10-phenanthroline adducts were synthesized and characterised by both experimental and computational methods. As only one complex could be isolated in crystalline form the comparison between the experimental and predicted IR, NMR and UV-Vis data was necessary to predict and confirm the structure of the other complexes. Polymeric structure was predicted for the $\mathrm{Ag}(\mathrm{I})$ complexes (23-33), where the silver ion has contacts with four different coumarin ligands and $\mathrm{Ag}-\mathrm{Ag}$ bond is doubly bridged by two carboxylate groups. Whereas for their phen adducts (34-44) a monodentate carboxylate binding of the coumarin ligand, and $\mathrm{N}, \mathrm{N}$-bidentate binding of the two phen ligands to the silver ion were proposed.

The complexes showed promising results against the tested bacterial strains and may have potential as therapeutic agents against infectious diseases. The strain specific inhibitory response of these complexes, observed during this study, could be attributed to the fact that their mode of action in Gram-negative bacteria is likely to be different to their mode of action in Gram-positive bacteria. The anti-Candida results were far more striking with the 1,10-phenanthroline adducts showing better antifungal activity than the silver(I) salt and were capable of inhibiting the growth of $C$. albicans by $50 \%$ at a concentration range of ca. 7 to $10 \mu \mathrm{M}$. This was comparable to the efficacy of Ketoconazole, a commonly prescribed anti-Candida therapeutic.

The general lack of solubility of the $\mathrm{Ag}(\mathrm{I})$ complexes studied may limit their application to topical infections or as additives in surface protection technologies. Indeed there are a number of commercially available products such as Foley catheters etc. which are impregnated with silver(I) additives. However, one of the derivatives isolated had improved solubility compared to all previous coumarin-based silver(I) complexes but did not show any enhanced antimicrobial activity. Cytotoxicity testing of that series of acetate derivatives against human-derived cell lines also did not reveal any structure activity relationship (SAR) but did indicate that the complexes had good activity against the clinically relevant HepG2 and A498 cell lines. Preliminary mechanistic studies using complex 31, $\mathrm{Ag}(3 \mathrm{Cl}-4 \mathrm{Me}-\mathrm{C}-7$ oxy-acet $)] \cdot 0.8 \mathrm{H}_{2} \mathrm{O}$, a complex which had good antimicrobial, antifungal and cytotoxic activity, indicated that the complex did not interact with DNA via intercalation, did not have nuclease activity but did have SOD mimetic activity. This is consistent with other recent findings on related complexes which indicated that silver(I) complexes may potentiate their activity though an antioxidative process which disrupts metabolism of the different cell types studied.

\section{Abbreviations}

MDR multi drug resistant

AIDS Acquired Immune Deficiency Syndrome

MRSA methicillin-resistant S. aureus

HIV human immunodeficiency virus

TSA trypticase soy agar

ROS reactive oxygen species

DNA deoxyribonucleic acid 


$\begin{array}{ll}\text { phen } & \text { 1,10-phenanthroline } \\ \text { SOD } & \text { superoxide dismutase } \\ \text { DFT } & \text { density functional theory } \\ \text { TDDFT } & \text { time dependent density functional theory } \\ \text { DMSO } & \text { dimethyl sulfoxide } \\ \text { TLC } & \text { Thin layer chromatographic } \\ \text { TGA } & \text { thermogravimetric analysis } \\ \text { DEPT } & \text { distortionless enhancement by polarization transfer } \\ \text { COSY } & \text { homonuclear correlation spectra } \\ \text { HSQC } & \text { Heteronuclear Single Quantum Correlation } \\ \text { HMBC } & \text { Heteronuclear Multiple Bond Correlation } \\ \text { NOESY } & \text { Nuclear Overhauser effect spectroscopy } \\ \text { ECP } & \text { effective core potential } \\ \text { TMS } & \text { tetramethylsilane } \\ \text { NCCLS } & \text { National Committee for Clinical Laboratory Standards } \\ \text { LB } & \text { Luria Bertani } \\ \text { NBT } & \text { nitroblue tetrazolium } \\ \text { PBS } & \text { phosphate-buffered saline } \\ \text { MTT } & \text { methylthiazolyldiphenyl-tetrazolium bromide } \\ \text { NCCLS } & \text { National Committee for Clinical Laboratory Standards } \\ \text { EtBr } & \text { ethidium bromide } \\ \text { PCM } & \text { Polarisable Continuum Model } \\ \text { Et } & \text { ethidium ion } \\ \text { EDTA } & \text { ethylenediaminetetraacetic acid } \\ \text { CT-DNA } & \text { calf thymus DNA } \\ \text { TES } & \text { N-[tris(hydroxymethyl)methyl]-2-aminoethanesulfonic acid } \\ \text { SC } & \text { supercoiled } \\ \text { DMF } & \text { dimethylformamide } \\ \text { OC } & \text { open circular }\end{array}$

\section{Acknowledgments}

This research was supported by the Technological Sector Research Programme, Strand III CRS-02 TA01-4 under the European Social Fund and by the Centre of Applied Science for Health, ITT Dublin funded under PRTLI-Cycle 4 (S and E Regional Operational Project Code 4138). All DFT calculations were performed on the MADARA computer cluster of the Bulgarian Academy of Sciences. This work has been carried out (in part) within the structures of the Facility for Optical Characterisation and Spectroscopy (now the FOCAS Institute, DIT) funded under The Irish National Development Plan 2000-2006 with assistance from the European Regional Development Fund.

\section{Appendix A. Supplementary data}

Supplementary data for compounds $\mathbf{3} 3$ have been deposited at the Cambridge Crystallographic Data Centre, deposition number CCDC 1437900. Supplementary data associated with this article can be found in the online version, at http://dx.doi.org/10.1016/j.jinorgbio. 2016.07.010.

\section{References}

[1] M.A. Moreno, T. Teshager, M.C. Porrero, M. Garcia, E. Escudero, C. Torres, L Dominguez, Vet. Microbiol. 120 (2007) 363-369.

[2] I.M. Gould, R. Cauda, S. Esposito, F. Gudiol, T. Mazzei, J. Garau, Int. J. Antimicrob. Agents 37 (2011) 202-209.

[3] S.S. Jean, P.R. Hsueh, Int. J. Antimicrob. Agents 37 (2011) 291-295.

[4] V. Kuete, S. Alibert-Franco, K.O. Eyong, B. Ngameni, G.N. Folefoc, J.R. Nguemeving, J.G. Tangmouo, G.W. Fotso, J. Komguem, B.M.W. Ouahouo, J.M. Bolla, J. Chevalier, B.T. Ngadjui, A.E. Nkengfack, J.M. Pages, Int. J. Antimicrob. Agents 37 (2011) $156-161$.

[5] R.N. Master, R.B. Clark, J.A. Karlowsky, J. Ramirez, J.M. Bordon, Int. J. Antimicrob. Agents 38 (2011) 291-295.

[6] http://www.who.int/mediacentre/news/releases/2015/antibiotic-resistanceacking/en/http://ec.europa.eu/health/antimicrobial_resistance/policy/index_en. htm.

[7] J.F. Kokai-Kun, T. Chanturiya, J.J. Mond, J. Antimicrob. Chemother. 60 (2007) 1051-1059.
[8] C. Appelt, A.K. Schrey, J.A. Soderhall, P. Schmieder, Bioorg. Med. Chem. Lett. 17 (2007) 2334-2337.

[9] O. Denis, C. Nonhoff, B. Byl, C. Knoop, S. Bobin-Dubreux, M.J. Struelens, J. Antimicrob. Chemother. 50 (2002) 383-391.

[10] M. Kandhasamy, K.D. Arunachalam, Afr. J. Biotechnol. 7 (2008) 1958-1961.

[11] J.L. Vincent, J. Rello, J. Marshall, E. Silva, A. Anzueto, C.D. Martin, R. Moreno, J. Lipman, C. Gomersall, Y. Sakr, K. Reinhart, E.I.G. Investigators, JAMA, J. Am. Med. Assoc. 302 (2009) 2323-2329.

[12] D. Nathwani, G. Raman, K. Sulham, M. Gavaghan, V. Menon, Antimicrob. Resist. Infect. Control 3 (2014) 32.

[13] Antibiotic Resistance Threat in the United States, CDC - Threat Report, 2013.

[14] L.S. Derengowski, C. De-Souza-Silva, S.V. Braz, T.M. Mello-De-Sousa, S.N. Bao, C.M. Kyaw, I. Silva-Pereira, Ann. Clin. Microbiol. Antimicrob. 8 (2009) 13.

[15] M. Weig, U. Gross, F. Muhlschlegel, Trends Microbiol. 6 (1998) 468-470.

[16] J.H. Shin, S.J. Kee, M.G. Shin, S.H. Kim, D.H. Shin, S.K. Lee, S.P. Suh, D.W. Ryang, J. Clin. Microbiol. 40 (2002) 1244-1248.

[17] I. Kustos, A. Nyul, T. Lorand, B. Kocsis, F. Kilar, J. Biochem. Biophys. Methods 69 (2006) 57-65.

[18] M.D. Richardson, J. Antimicrob. Chemother. 56 (2005) 5-11.

[19] M.P. Patel, A.T. Cruchley, D.C. Coleman, H. Swai, M. Braden, D.M. Williams, Biomaterials 22 (2001) 2319-2324.

[20] D. Maubon, C. Garnaud, T. Calandra, D. Sanglard, M. Cornet, Intensive Care Med. 40 (2014) 1241-1255.

[21] B.S. Creaven, D.A. Egan, K. Kavanagh, M. McCann, A. Noble, B. Thati, M. Walsh, Inorg. Chim. Acta 359 (2006) 3976-3984.

[22] B.S. Creaven, D.A. Egan, K. Kavanagh, M. McCann, M. Mahon, A. Noble, B. Thati, M Walsh, Polyhedron 24 (2005) 949-957.

[23] K. Nomiya, H. Yokoyama, J. Chem. Soc. Dalton Trans. (2002) 2483-2490.

[24] N.C. Kasuga, M. Sato, A. Amano, A. Hara, S. Tsuruta, A. Sugie, K. Nomiya, Inorg. Chim. Acta 361 (2008) 1267-1273.

[25] H.V.R. Dias, K.H. Batdorf, M. Fianchini, H.V.K. Diyabalanage, S. Carnahan, R. Mulcahy A. Rabiee, K. Nelson, L.G. van Waasbergen, J. Inorg. Biochem. 100 (2006) 158-160.

[26] K. Nomiya, R. Noguchi, M. Oda, Inorg. Chim. Acta 298 (2000) 24-32.

[27] N.P.E. Barry, P.J. Sadler, Chem. Commun. 49 (2013) 5106-5131.

[28] K.D. Mjos, C. Orvig, Chem. Rev. 114 (2014) 4540-4563.

[29] Z.F. Sun, F.C. Lv, L.J. Cao, L. Liu, Y. Zhang, Z.G. Lu, Angew. Chem. Int. Ed. 54 (2015) 7944-7948.

[30] I. Irwansyah, Y.Q. Li, W.X. Shi, D.P. Qi, W.R. Leow, M.B.Y. Tang, S.Z. Li, X.D. Chen, Adv Mater. 27 (2015) 648-654.

[31] Z.Z. Zhang, T. He, M.Y. Yuan, R.J. Shen, L. Deng, L.Z. Yi, Z.F. Sun, Y. Zhang, Chem. Commun. 51 (2015) 15862-15865.

[32] M.E. Riveiro, N. De Kimpe, A. Moglioni, R. Vazquez, F. Monczor, C. Shayo, C. Davio, Curr. Med. Chem. 17 (2010) 1325-1338.

[33] M. Sullivan, A.F.A. Kia, M. Long, M. Walsh, K. Kavanagh, S. McClean, B.S. Creaven, Polyhedron 67 (2014) 549-559.

[34] S. Jaiswal, K. Bhattacharya, M. Sullivan, M. Walsh, B.S. Creaven, F. Laffir, B. Duffy, P. McHale, Colloids Surf., B 102 (2013) 412-419.

[35] A. Smith, R. Rowan, M. McCann, K. Kavanagh, Biometals 25 (2012) 611-616.

[36] J.R. Morones-Ramirez, J.A. Winkler, C.S. Spina, J.J. Collins, Sci. Transl. Med. 5 (2013) 190ra81.

[37] L. Thornton, V. Dixit, L.O. Assad, T.P. Ribeiro, D.D. Queiroz, A. Kellett, A. Casey, J. Colleran, M.D. Pereira, G. Rochford, M. McCann, D. O'Shea, R. Dempsey, S McClean, A.F. Kia, M. Walsh, B. Creaven, O. Howe, M. Devereux, J. Inorg. Biochem. 159 (2016) 120-132.

[38] B. Thati, A. Noble, R. Rowan, B.S. Creaven, M. Walsh, M. McCann, D. Egan, K. Kavanagh, Toxicol. in Vitro 21 (2007) 801-808.

[39] B.S. Creaven, D.A. Egan, D. Karcz, K. Kavanagh, M. McCann, M. Mahon, A. Noble, B. Thati, M. Walsh, J. Inorg. Biochem. 101 (2007) 1108-1119.

[40] M. Geraghty, M. McCann, M. Devereux, F. Cronin, M. Curran, V. McKee, Metal-Based Drugs 6 (1999) 41-48.

[41] M. Devereux, D. O'Shea, M. O'Connor, H. Grehan, G. Connor, M. McCann, G. Rosair, F. Lyng, A. Kellett, M. Walsh, D. Egan, B. Thati, Polyhedron 26 (2007) 4073-4084.

[42] M. Mccann, M. Devereux, C. Cardin, M. Convery, Polyhedron 13 (1994) 221-226.

[43] P.R. Reddy, A. Shilpa, N. Raju, P. Raghavaiah, J. Inorg. Biochem. 105 (2011) 1603-1612.

[44] S.A. Patil, S.N. Unki, A.D. Kulkarni, V.H. Naik, P.S. Badami, Spectrochim. Acta A 79 (2011) 1128-1136.

[45] G.M. Sheldrick, TWINABS, University of Göttingen, Germany, 2009.

[46] Bruker (2011), APEX2 V2011.4-1, M. Bruker AXS Inc., Wisconsin, USA (Ed.).

[47] G.M. Sheldrick, Acta Crystallogr. A 64 (2008) 112-122.

[48] O.V. Dolomanov, L.J. Bourhis, R.J. Gildea, J.A.K. Howard, H. Puschmann, J. Appl. Crystallogr. 42 (2009) 339-341.

[49] Gaussian 09, Revision A.02, M. J. Frisch, G. W. Trucks, H. B. Schlegel, G. E. Scuseria, M. A. Robb, J. R. Cheeseman, G. Scalmani, V. Barone, B. Mennucci, G. A. Petersson, H. Nakatsuji, M. Caricato, X. Li, H. P. Hratchian, A. F. Izmaylov, J. Bloino, G. Zheng, J. L Sonnenberg, M. Hada, M. Ehara, K. Toyota, R. Fukuda, J. Hasegawa, M. Ishida, T. Nakajima, Y. Honda, O. Kitao, H. Nakai, T. Vreven, J. A. Montgomery, Jr., J. E. Peralta, F. Ogliaro, M. Bearpark, J. J. Heyd, E. Brothers, K. N. Kudin, V. N. Staroverov, R. Kobayashi, J. Normand, K. Raghavachari, A. Rendell, J. C. Burant, S. S. Iyengar, J. Tomasi, M. Cossi, N. Rega, J. M. Millam, M. Klene, J. E. Knox, J. B. Cross, V. Bakken, C. Adamo, J. Jaramillo, R. Gomperts, R. E. Stratmann, O. Yazyev, A. J. Austin, R. Cammi, C. Pomelli, J. W. Ochterski, R. L. Martin, K. Morokuma, V. G. Zakrzewski, G. A. Voth, P. Salvador, J. J. Dannenberg, S. Dapprich, A. D. Daniels, Ö. Farkas, J. B. Foresman, J. V. Ortiz, J. Cioslowski, and D. J. Fox, Gaussian, Inc., Wallingford CT, 2009

[50] C.T. Lee, W.T. Yang, R.G. Parr, Phys. Rev. B 37 (1988) 785-789.

[51] A.D. Becke, J. Chem. Phys. 98 (1993) 5648-5652. 
[52] I. Georgieva, N. Trendafilova, B.S. Creaven, M. Walsh, A. Noble, M. McCann, Chem. Phys. 365 (2009) 69-79.

[53] T. Mihaylov, N. Trendafilova, I. Kostova, I. Georgieva, G. Bauer, Chem. Phys. 327 (2006) 209-219.

[54] M. Dolg, H. Stoll, A. Savin, H. Preuss, Theor. Chim. Acta 75 (1989) 173-194.

[55] M. Dolg, P. Fulde, W. Kuchle, C.S. Neumann, H. Stoll, J. Chem. Phys. 94 (1991) 3011-3017.

[56] http://www.chemcraftprog.com.

[57] E. Cances, B. Mennucci, J. Tomasi, J. Chem. Phys. 107 (1997) 3032-3041.

[58] M. Cossi, V. Barone, B. Mennucci, J. Tomasi, Chem. Phys. Lett. 286 (1998) 253-260

[59] B. Mennucci, J. Tomasi, J. Chem. Phys. 106 (1997) 5151-5158.

[60] J.L. Rodriguez-Tudela, M. Cuenca-Estrella, T.M. Diaz-Guerra, E. Mellado, J. Clin. Microbiol. 39 (2001) 2513-2517.

[61] T. Mosmann, J. Immunol. Methods 65 (1983) 55-63.

62] A. Kellett, M. O'Connor, M. McCann, M. McNamara, P. Lynch, G. Rosair, V. Mckee, B. Creaven, M. Walsh, S. McClean, A. Foltyn, D. O'Shea, O. Howe, M. Devereux, Dalton Trans. 40 (2011) 1024-1027.

[63] K.B. Gudasi, M.S. Patil, R.S. Vadavi, Eur. J. Med. Chem. 43 (2008) 2436-2441.

[64] Z.H. Chohan, H.A. Shad, M.H. Youssoufi, T. Ben Hadda, Eur. J. Med. Chem. 45 (2010) 2893-2901.

[65] M.E. Katsarou, E.K. Efthimiadou, G. Psomas, A. Karaliota, D. Vourloumis, J. Med. Chem. 51 (2008) 470-478.

[66] A.I. Mosa, A.A.A. Emara, J.M. Yousef, A.A. Saddiq, Spectrochim. Acta A 81 (2011) 35-43.

67] G.B. Deacon, R.J. Phillips, Coord. Chem. Rev. 33 (1980) 227-250.

[68] M. Geraghty, V. Sheridan, M. McCann, M. Devereux, V. McKee, Polyhedron 18 (1999) 2931-2939.
69] B. Morzyk-Ociepa, D. Michalska, Spectrochim. Acta A 59 (2003) 1247-1254.

[70] S. Chimichi, M. Boccalini, B. Cosimelli, Tetrahedron 58 (2002) 4851-4858.

[71] L. Pazderski, J. Tousek, J. Sitkowski, L. Kozerski, R. Marek, E. Szlyk, Magn. Reson. Chem. 45 (2007) 24-36.

[72] Z.H. Wei, X. Xie, J. Zhao, L.M. Huang, X.M. Liu, Inorg. Chim. Acta 387 (2012) 277-282.

[73] B. Coyle, K. Kavanagh, M. McCann, M. Devereux, M. Geraghty, Biometals 16 (2003) 321-329.

[74] M. Geraghty, J.F. Cronin, M. Devereux, M. McCann, Biometals 13 (2000) 1-8.

[75] M. McCann, R. Curran, M. Ben-Shoshan, V. McKee, A.A. Tahir, M. Devereux, K. Kavanagh, B.S. Creaven, A. Kellett, Dalton Trans. 41 (2012) 6516-6527.

[76] M. Mujahid, A.F.A. Kia, B. Duff, D.A. Egan, M. Devereux, S. McClean, M. Walsh, N. Trendafilova, I. Georgieva, B.S. Creaven, J. Inorg. Biochem. 153 (2015) 103-113.

[77] S. Thangamani, H. Mohammad, M.F.N. Abushahba, T.J.P. Sobreira, V.E. Hedrick, L.N. Paul, M.N. Seleem, Sci. Rep. Uk 6 (2016) 22571.

[78] L. Zhang, K.V. Kumar, S. Rasheed, S.L. Zhang, R.X. Geng, C.H. Zhou, Med. Chem. Commun. 6 (2015) 1303-1310.

[79] G. Raju, S. Vishwanath, A. Prasad, B.K. Patel, G. Prabusankar, J. Mol. Struct. 1107 (2016) 291-299.

[80] J.C. Joyner, W.F. Hodnick, A.S. Cowan, D. Tamuly, R. Boyd, J.A. Cowan, Chem. Commun. 49 (2013) 2118-2120.

[81] M.A. Franco-Molina, E. Mendoza-Gamboa, P. Zapata-Benavides, P. Castillo-Tello, C.E. Isaza-Brando, D. Zamora-Avila, L.G. Rivera-Morales, D.F. Miranda-Hernandez, C.A. Sierra-Rivera, M.E. Vera-Garcia, R.S. Tamez-Guerra, C. Rodriguez-Padilla, Immunopharmacol. Immunotoxicol. 32 (2010) 637-646.

[82] Z.A. Akram Ranjbar, F. Khajavi, H. Ghasemi, Nanomedicine J. 1 (2014) 205-211. 